\title{
Modulation of the activity of histone acetyltransferases by long chain alkylidenemalonates (LoCAMs)
}

\author{
Ciro Milite ${ }^{\mathrm{a}}$, Sabrina Castellano ${ }^{\mathrm{a}}$, Rosaria Benedetti ${ }^{\mathrm{b}, \mathrm{c}}$, Alessandra Tosco $^{\mathrm{a}}$, Carmen Ciliberti $^{\mathrm{a}}$, \\ Caterina Vicidomini ${ }^{a}$, Ludovic Boully ${ }^{a}$, Gianluigi Franci ${ }^{\text {b,d }}{ }^{\text {, Lucia Altucci }}{ }^{\text {b,d,* }}$, Antonello Mai ${ }^{\mathrm{e}, *}$, \\ Gianluca Sbardella ${ }^{a, *}$ \\ a Dipartimento di Scienze Farmaceutiche, Università degli Studi di Salerno, Via Ponte Don Melillo, 84084 Fisciano (SA), Italy \\ ${ }^{\mathrm{b}}$ Dipartimento di Patologia Generale, Seconda Università degli Studi di Napoli, Vico L. De Crecchio 7, 80138 Napoli, Italy \\ ${ }^{\mathrm{c}}$ Dipartimento di Fisica, Università di Napoli Federico II, Napoli, Italy \\ d IGB-CNR, Via Pietro Castellino, 80100, Napoli, Italy

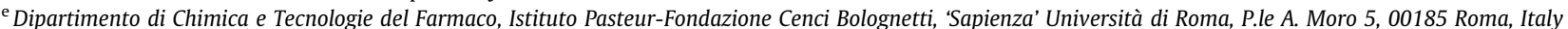

\section{A R T I C L E I N F O}

\section{Article history:}

Received 19 November 2010

Revised 5 January 2011

Accepted 10 January 2011

Available online 14 January 2011

\section{Keywords:}

Histone acetyltransferases modulators

p300/CBP

PCAF activator

KAT

Epigenetics

\begin{abstract}
A B S T R A C T
A novel class of KAT modulators (long chain alkylidenemalonates, LoCAMs) has been identified. Variations of the alkyl chain length can change the activity profile from inhibition of both KAT3A/KAT2B (as derivative $\mathbf{2 a}$ ) to the peculiar profile of pentadecylidenemalonate $\mathbf{1 b}$, the first activator/inhibitor of histone acetyltransferases. Together with the powerful apoptotic effect (particularly notable if considering that anacardic acid and other KAT inhibitors are not cell permeable) appoint them as valuable biological tools to understand the mechanisms of lysine acetyltransferases.
\end{abstract}

(c) 2011 Elsevier Ltd. All rights reserved.

\section{Introduction}

Lysine acetylation is among the prominent posttranslational modifications in eukaryotic cells. Crosstalking between this and other identified posttranslational modifications ${ }^{1,2}$ such as methylation, ubiquitination, and phosphorylation give rise to a dense network which constitutes the histone $\operatorname{code}^{2-4}$ and is crucial in modulating chromatin-based transcriptional control and shaping inheritable epigenetic programs. First identified nearly 50 years ago, ${ }^{5}$ the acetylation state of histones within chromatin is correlated with gene regulation, with hypoacetylated histones being associated with transcriptionally repressed genes and hyperacetylated histones with transcriptionally active ones. Like histones, many non-histone proteins are subject to acetylation ${ }^{6}$ and a similar crosstalk (named 'protein modification code') (3,7 $^{3}$ with other posttranslational modifications is now known to occur in more than 80 transcription factors (i.e., p53), ${ }^{8}$ many other nuclear regulators (i.e., $\boldsymbol{\alpha}$-tubulin), ${ }^{9}$ and various cytoplasmic proteins. ${ }^{7,10}$ As a

\footnotetext{
* Corresponding authors. Tel.: +39 081566 7569; fax: +39 081450169 (L.A.); tel.: +39 064991 3392; fax: +39 06491491 (A.M.); tel.: +39 08996 9770; fax: +39 089969602 (G.S.).

E-mail addresses: lucia.altucci@unina2.it (L. Altucci), antonello.mai@uniroma1.it (A. Mai), gsbardella@unisa.it (G. Sbardella).
}

result, lysine acetylation is not only crucial in the nucleus but also appears to be important for the regulation of different cytoplasmic processes, including cytoskeleton dynamics, energy metabolism, endocytosis, autophagy, and even signaling from the plasma membrane. ${ }^{11-13}$ In addition, reversible lysine acetylation may alter enzymatic activity to allow the cell to respond to environmental changes in metabolic demands and it has been proposed as an evolutionarily conserved mechanism for the regulation of cell functions. ${ }^{14-16}$

Protein acetylation level is a consequence of the balance between the opposite activities of protein acetyltransferases (KATs) ${ }^{17}$ and deacetylases (KDACs), ${ }^{18}$ and its deregulation has been linked to several diseases, ${ }^{19,20}$ including cancer, ${ }^{21-29}$ inflammation ${ }^{30-33}$ and, probably, neurodegenerative diseases. ${ }^{34-38}$ Thus, lysine acetylation is a promising target for therapeutic development. As a matter of fact, a number of KDAC inhibitors are currently undergoing clinical evaluation for efficacy in the treatment of human tumours $^{39,40}$ and two of them, suberoylanilide hydroxamic acid (SAHA, vorinostat), ${ }^{41}$ and romidepsin (FR901228, Istodax) ${ }^{42}$ were approved by the U.S. Food and Drug Administration (FDA) for the treatment of advanced cutaneous T-cell lymphoma.

On the contrary, KATs are less validated as chemotherapeutic targets. They can be organized into families based on primarystructure homology within the catalytic domain and similarities 
in their biological function. Four of these families have been extensively studied: the Gcn5-related $N$-acetyltransferase (GNAT) family, the E1A-associated protein of $300 \mathrm{kDa}$ (p300)/CREB-binding protein (CBP) family, the MYST family; and the regulation of Ty1 transposition gene product 109 (Rtt109) family. ${ }^{7,17,43-46}$ Several other KAT families have been identified, but they have been studied less extensively. $6,14,17,47$

Misregulation of the activity of KAT enzymes has been linked to a broad set of diseases ranging from cancer to central nervous system pathologies. Yet, at least in cancer, their role cannot be simply generalized as they can function either as tumor suppressors or promoters depending on different tumor types and development stages. ${ }^{14,19}$ Therefore, cell-permeable, selective modulators of these enzymes could be invaluable tools for reverse chemical genetics studies ${ }^{48,49}$ and to assess the implication of KATs in several pathologies. Moreover, they can represent starting points for the design of novel epigenetic drugs.

Differently from KDAC proteins, just a few small molecule inhibitors of KATs have been reported to date (Fig. 1), with various degrees of selectivity and cell permeability. Peptide-CoA conjugates (Lys-CoA and H3-CoA-20) have been described as potent and selective bisubstrate inhibitors for KAT3B (p300) and KAT2B (PCAF), however the lack of cell permeability represents a drawback. ${ }^{34,50}$ A few natural products like anacardic acid, ${ }^{51}$ garcinol, ${ }^{52}$ curcumin, ${ }^{53}$ plumbagin, ${ }^{54}$ guttiferone $A^{55}$ as well as some analogues $^{56-60}$ or semi-synthetic derivatives ${ }^{32}$ have also been reported as inhibitors of different classes of KATs. Isothiazolones were disclosed as cell-permeable and potent inhibitors of KAT2B, but their chemical reactivity limits their specificity. ${ }^{61-64}$ Cell-permeable KAT2A (GCN5)-selective inhibitors like the $\gamma$-butyrolactone MB$3^{65}$ and a few quinoline derivatives ${ }^{66}$ were also reported. On the other side, only $\mathrm{N}$-(4-chloro-3-trifluoromethyl-phenyl)-2-ethoxy6-pentadecyl-benzamide (CTPB, Fig. 2$)^{51}$ and nemorosone ${ }^{55}$ were reported to selectively activate p300 HAT activity.

Recently we reported a unique activity profile for pentadecylidenemalonate 1b (Fig. 2), a simplified analogue of anacardic acid. This compound exhibits a good inhibitory activity against KAT3A/ $\mathrm{B}(\mathrm{CBP} / \mathrm{p} 300)$ and intriguingly, a significant increase of the acetylating activity of KAT2B. ${ }^{67}$ This observation suggests that it is the first activator/inhibitor of histone acetyltransferases.

With the aim to derive structure-activity relationships, we decided to explore the effect on the biological activity of the length of the alkyl chain, the nature of the carbonyl function, the eventual presence of substituents, and the rigidity/flexibility of the scaffold (Fig. 3). Herein we thus report the synthesis of a number of analogues of compound $\mathbf{1 b}$, as well as the evaluation of their biological effects on the activity of KAT enzymes. In addition, the effects of tested compounds on cell cycle and apoptosis induction on U937 cells were also evaluated.

\section{Chemistry}

Most of the novel compounds were prepared by reacting a 1,3-dicarbonyl derivative with the proper electrophile. In fact, derivatives 1-3 were prepared, respectively, (Scheme 1) by Knoevenagel condensation of diethyl malonate or pentane-2,4-dione

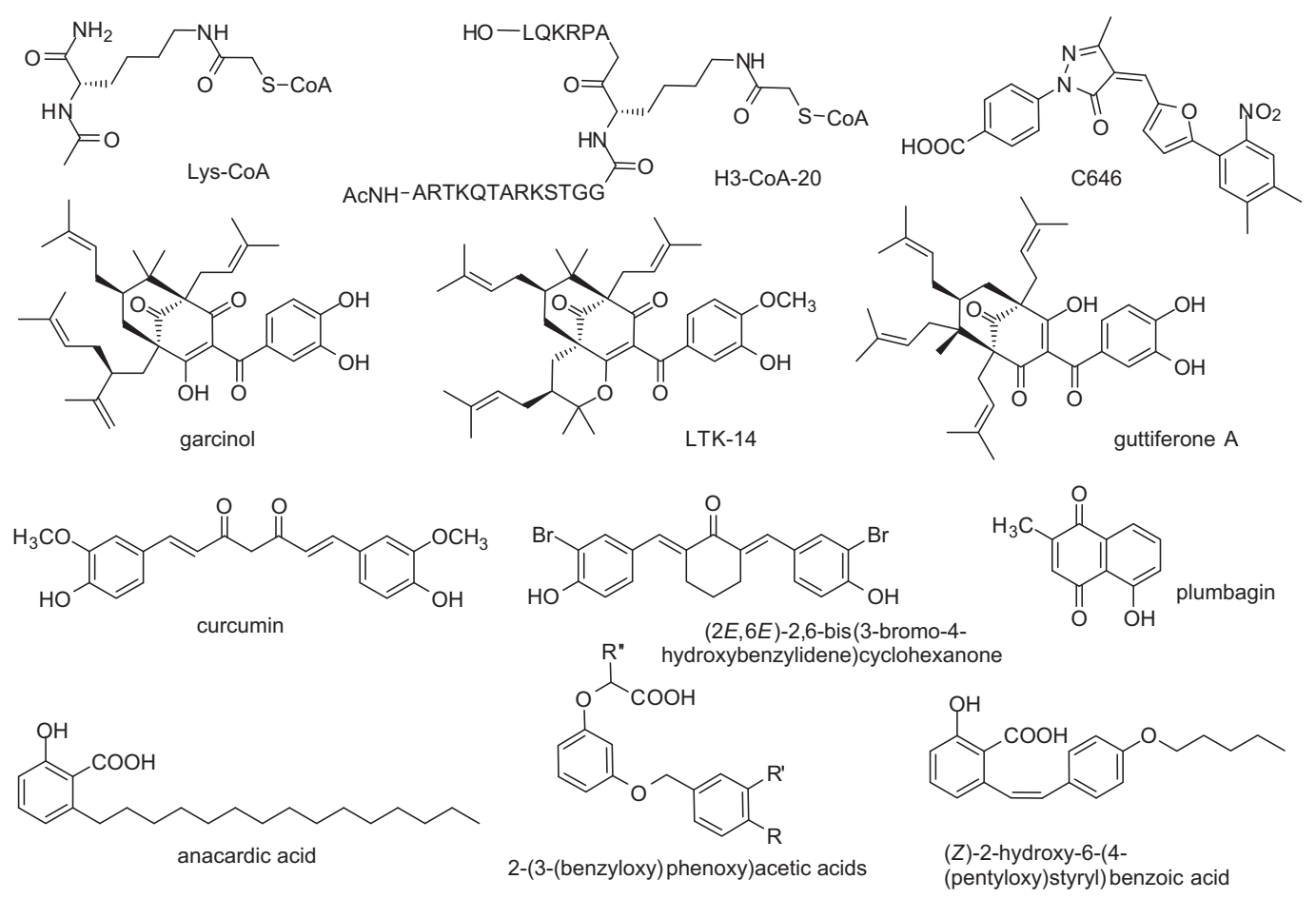

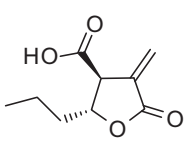

MB-3

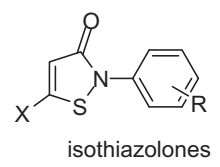

$\mathrm{X}=\mathrm{H}, \mathrm{Cl}$

$\mathrm{R}=\mathrm{NO}_{2}, \mathrm{Cl}, \mathrm{CF}_{3}$, OMe, COOEt<smiles>[R]c1nc2ccccc2cc1C(=O)OCC</smiles>

$\mathrm{MC1626} \mathrm{R}=\mathrm{CH}_{3}$
$\mathrm{MC1752} \mathrm{R}=\mathrm{H}$<smiles>CCCCCc1nc2ccccc2c(O)c1C(=O)O</smiles>

MC1823

Figure 1. Known KAT inhibitors. 


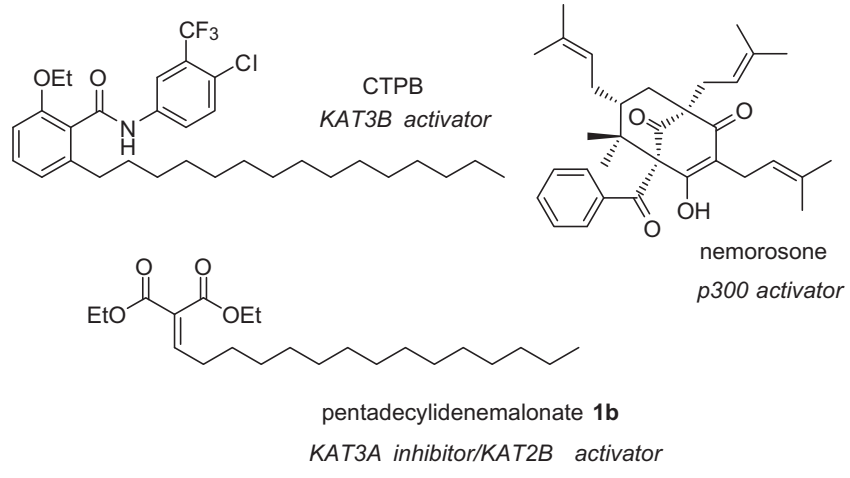

Figure 2. KAT activators.

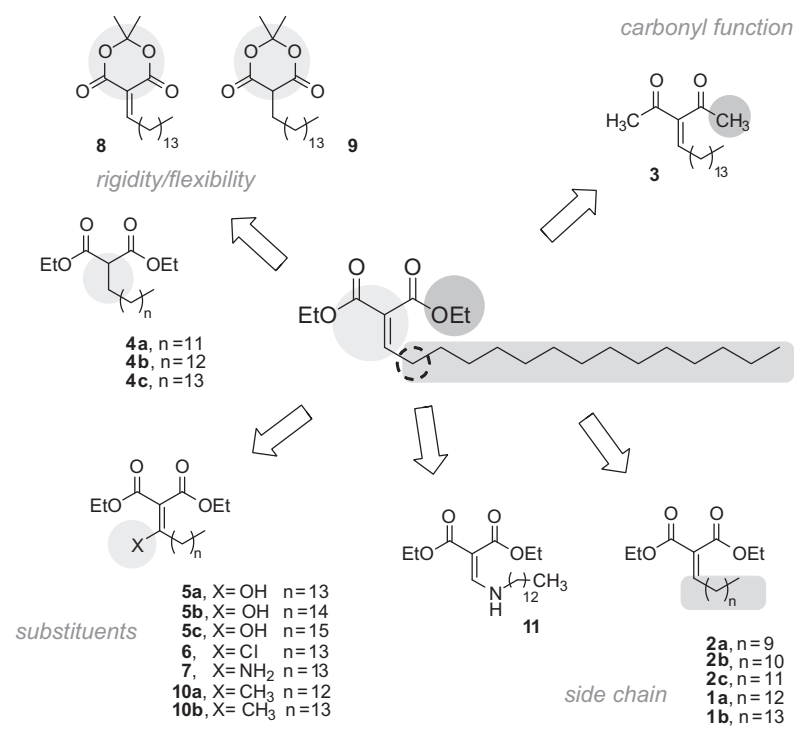

Figure 3. Compounds screened on U937 cells.

with aldehydes 12a-e, commercially available or obtained from the corresponding alcohols by oxidation with 1,1,1-triacetoxy1,1-dihydro-1,2-benziodoxol-3(1H)-one (Dess-Martin periodinane, DMP). ${ }^{67,68}$ The monoalkylation of diethyl malonate with the appropriate alkyl bromide in the presence of sodium hydride in dry $\mathrm{THF}^{69}$ gave derivatives $\mathbf{4 a}-\mathbf{c},{ }^{69-71}$ while the acylation of the $\beta$-ketoester with tetradecanoyl, pentadecanoyl, or hexadecanoyl imidazolide in the presence of magnesium dichloride and triethylamine furnished derivatives $\mathbf{5 a}-\mathbf{c}^{67}$ The tetradecyl substituted compound 5a was treated with phosphorus oxychloride or with ammonium acetate to obtain chloro-substituted or amino-substituted derivatives $\mathbf{6}$ and 7, respectively (Scheme 1).

Similarly, when Meldrum's acid was used as 1,3-dicarbonyl compound in the Knoevenagel condensation or in the alkylation in the presence of sodium hydride, derivatives $\mathbf{8}$ and $\mathbf{9}$ were obtained, respectively (Scheme 2).

Alkan-2-ylidene malonates $\mathbf{1 0 a}, \mathbf{b}$ were obtained by reacting the corresponding alkan-2-ones with triethyl phosphonoacetate in the presence of sodium hydride in the Horner-Wadsworth-Emmons reaction conditions. The resulting mixture of $E$ and $Z \alpha, \beta$-unsaturated esters was then treated with lithium diisopropylamide and ethyl chloroformate to yield the desired derivatives (Scheme 3).

Finally, tridecylamino methylenemalonate $\mathbf{1 1}$ was obtained by refluxing diethyl ethoxymethylenemalonate with tridecylamine in anhydrous ethanol (Scheme 4).

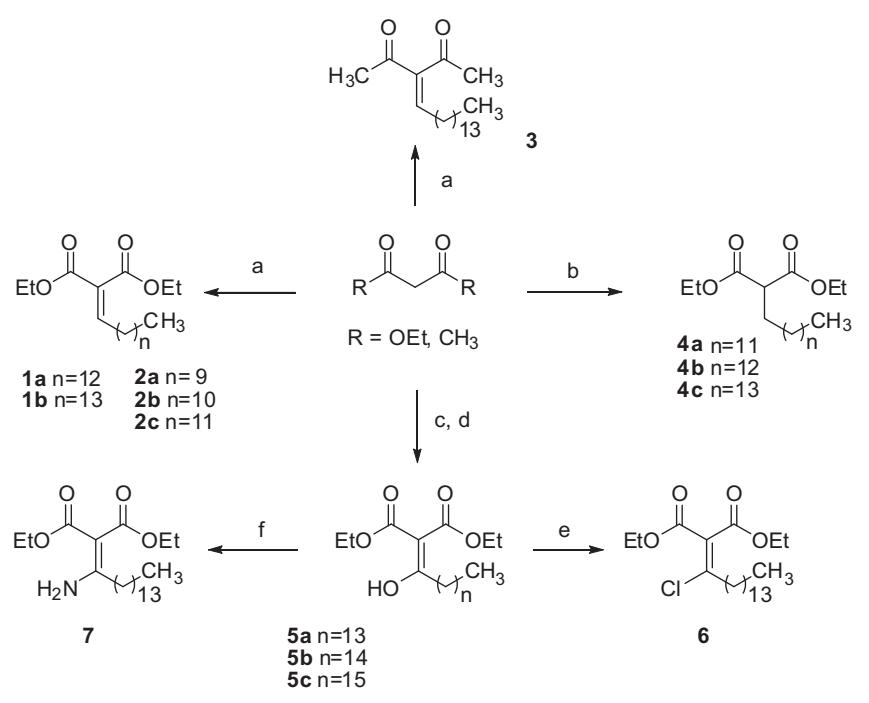

Scheme 1. Reagents and conditions: (a) alkyl aldehyde 12a-e, acetic acid, piperidine, dichloromethane; (b) alkyl bromide, $\mathrm{NaH}, \mathrm{THF}, 0^{\circ} \mathrm{C}(100 \mathrm{~min}), \mathrm{rt}(2 \mathrm{~h})$ and $70{ }^{\circ} \mathrm{C}(15 \mathrm{~h})$; (c) acylimidazolide, $\mathrm{MgCl}_{2}, \mathrm{Et}_{3} \mathrm{~N}$, acetonitrile, rt; (d) $13 \% \mathrm{HCl}$, rt; (e) $\mathrm{POCl}_{3}, \mathrm{TEA}$; (f) $\mathrm{NH}_{4} \mathrm{OAc}, \mathrm{EtOH}$.

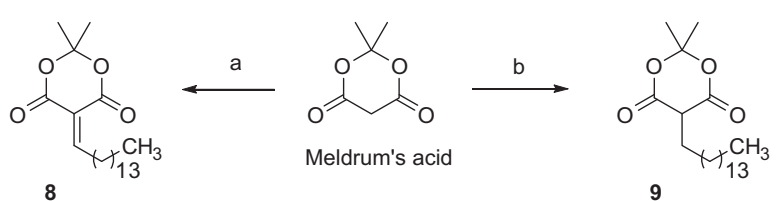

Scheme 2. Reagents and conditions: (a) alkyl aldehyde 12b, acetic acid, piperidine, dichloromethane; (b) alkyl bromide, $\mathrm{NaH}, \mathrm{THF}, 0^{\circ} \mathrm{C}(100 \mathrm{~min}), \mathrm{rt}(2 \mathrm{~h})$ and $70{ }^{\circ} \mathrm{C}$ (15 h).

\section{Biology}

\subsection{KAT3A and KAT2B inhibitory assays}

We previously reported that pentadecylidenemalonate $\mathbf{1 b}$ possess a peculiar activity profile against acetyltransferases. ${ }^{67}$ Thus, compounds 1-11 were tested for inhibition of the recombinant acetyltransferase enzymes KAT3A (CBP, Fig. 4A) and KAT2B (Fig. 4B), using anacardic acid $(A A)^{51}$ as reference compound (at $50 \mu \mathrm{M}$ ). In agreement with what we previously reported, the inferior homologues of $\mathbf{1 b}$ (with the exception of the tridecylidene derivative $\mathbf{2 c}$ which resulted inactive) as well as the $\beta$-diketone $\mathbf{3}$ displayed a strong inhibition against recombinant KAT3A (in the range $79-83 \%$ ), thereby being more powerful than AA when tested in the same conditions ( $62 \%$ of inhibition at $50 \mu \mathrm{M}$ ). Among the other derivatives, only $\mathbf{5 a}$ exhibited a moderate enzyme inhibition (52\%), the others being scarcely active (Fig. 4A). Similarly to $\mathbf{1 b}$, derivative 1a induced an increase of the acetylating activity of KAT2B (Fig. 4B). A slight increase of the enzymatic activity was also detectable for compounds $\mathbf{5 a}$ and $\mathbf{1 1}$ (characterized by the presence on the double bond of the lead scaffold of a $\mathrm{OH}$ and a $\mathrm{NH}$ group, respectively). All the other derivatives were inactive or displayed just a moderate inhibition, with the exception of the chlorosubstituted malonate $\mathbf{6}$ which displayed a strong activating effect.

\subsection{Western blot analyses}

The effect of compounds 1-11 on the acetylation levels of histone (H3 terminal tails) or non-histone ( $\alpha$-tubulin) proteins was assessed in human leukemia U937 cell line (Fig. 5A), and in human 


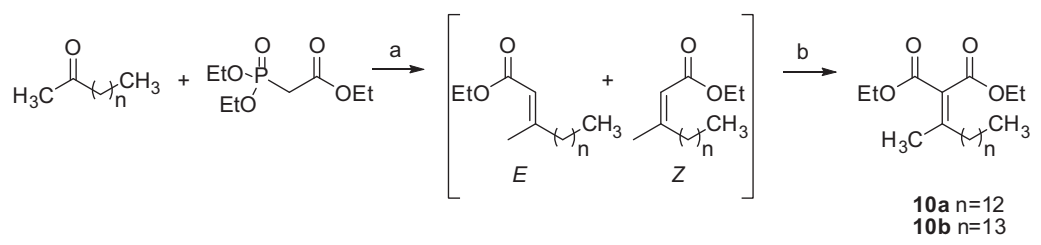

Scheme 3. Reagents and conditions: (a) NaH, THF, $-40^{\circ} \mathrm{C}$; (b) ClCOOEt, LDA, HMPA, THF, $-78^{\circ} \mathrm{C}$.

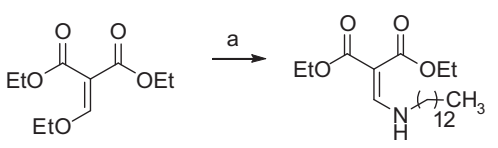

11

Scheme 4. Reagents and conditions: (a) tridecylamine, EtOH, reflux.

breast cancer MCF-7 cells (Fig. 5B), respectively. Cells were incubated with vehicle, tested compounds or with the reference compound suberoylanilide hydroxamic acid (SAHA, at $5 \mu \mathrm{M}$ ), a well-known KDAC inhibitor ${ }^{41}$ able to increase histone $\mathrm{H} 3$ as well as the non-histone substrate $\alpha$-tubulin acetylation levels. As shown by Western blot analysis (Fig. 5), the behavior of compound 1a in these assays was quite similar to what we previously observed with 1b. In fact, both compounds produce an increase of the $\mathrm{H} 3$ acetylation level, similar (even if less pronounced) to the one induced by SAHA (Fig. 5A) but without affecting KDAC activity (not shown). Moreover, while SAHA exhibited a marked hyperacetylating effect on both substrates, compounds 1a and 1b produced no detectable effect ${ }^{72}$ on the acetylation level of the non-histone substrate $\alpha$-tubulin (Fig. 5B). On the contrary, derivatives $\mathbf{2 a}$ and $\mathbf{2 b}$ and, to a lesser extent, derivative $\mathbf{3}$ induced a significant hypoacetylation of the $\mathrm{H} 3$ histone substrate in the same conditions (Fig. 5A). No effect was detectable on $\alpha$-tubulin acetylation. The effects of all the other derivatives were comparable to control, with the exception of derivative $\mathbf{5 b}$, which induced a strong $\alpha$-tubulin hyperacetylation at $15 \mu \mathrm{M}$, and derivative 11, which shows a weak but distinct dose-dependent hyperacetylation of the same substrate (Fig. 5B).
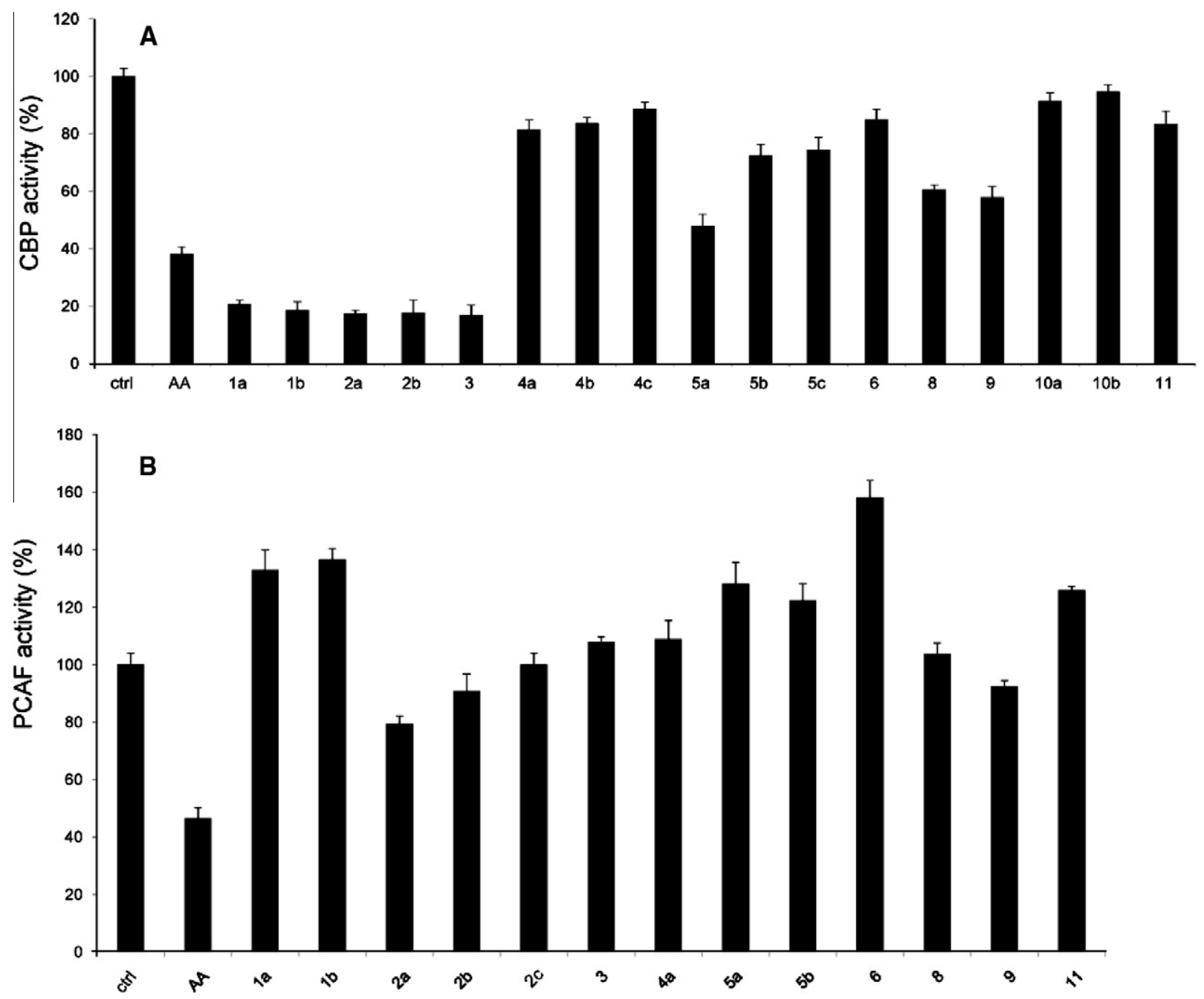

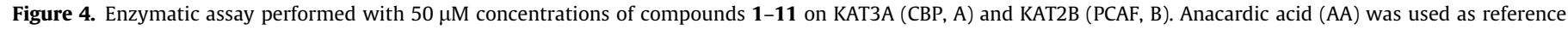
compound at $50 \mu \mathrm{M}$ concentration. 
A

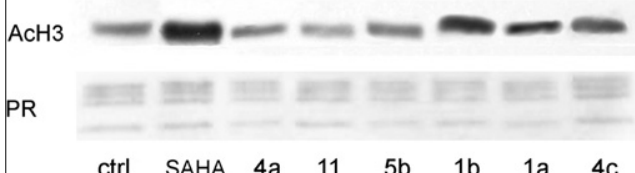

B

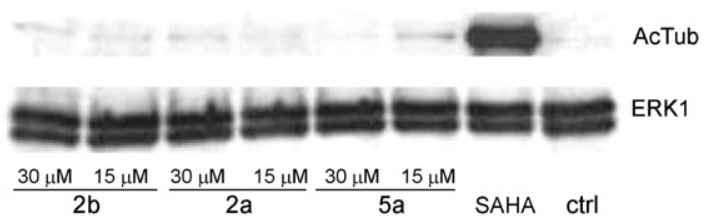

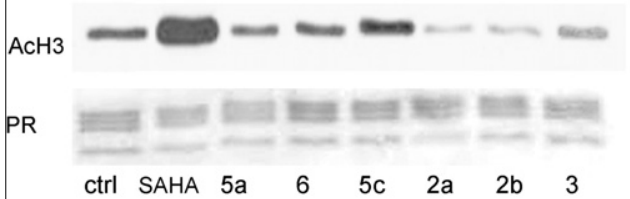
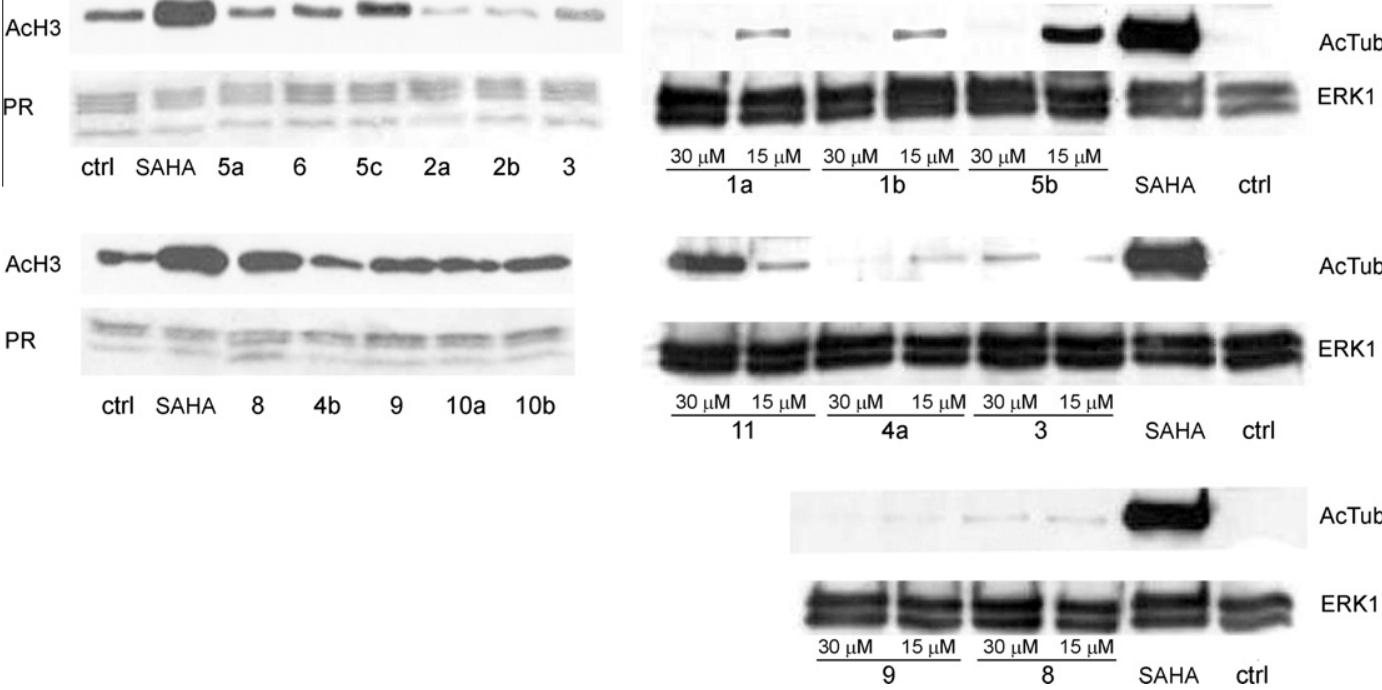

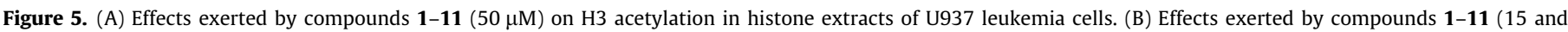

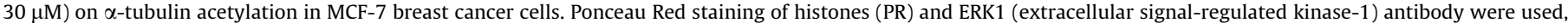
respectively, to check for equal loading. SAHA ( $5 \mu \mathrm{M})$ was used as reference compound.

\subsection{In-cell evaluation. Effects on cell cycle and apoptosis induction on human leukemia U937 cell line}

As cell permeability is a crucial issue for modulators of histone modifying enzymes, ${ }^{73}$ all the derivatives were then screened for their effects on cell cycle, apoptosis induction, and granulocytic differentiation in the human leukemia U937 cell line, using anacardic acid $(\mathrm{AA})^{51}$ as reference compound. After $30 \mathrm{~h}$ of treatment at $50 \mu \mathrm{M}$, compounds $\mathbf{1 a}, \mathbf{b}$ and $\mathbf{2 a}, \mathbf{b}$ were able to arrest the cell cycle in the $S$ phase (Fig. $6 \mathrm{~A})^{74}$ and, more importantly, displayed a strong apoptosis-inducing effect (51.8\%, 94.4\%, 25.4\% and 60.2\%, respectively; Fig. 6C). In the same conditions, the effects on cell cycle and apoptosis induction of derivative $\mathbf{3}$ were significantly lower, being barely detectable for all the other compounds, particularly when the experiment was repeated at lower concentration $(25 \mu \mathrm{M}$, Fig. $6 \mathrm{~B}$ and D). For the most active derivatives, $\mathbf{1} \mathbf{a}, \mathbf{b}$ and $\mathbf{2 a}, \mathbf{b}$, a dose-response study was also performed. U937 cells were incubated for $30 \mathrm{~h}$ at $37^{\circ} \mathrm{C}$ in the absence (control) or presence of increasing concentrations (5-200 $\mu \mathrm{M})$ of tested compounds. Interestingly, again the length of the aliphatic side chain seems crucial for biological activity, similarly to what reported by Giannis for analogues of MB-3. 65

In fact, as shown in Figure 6E, compounds $\mathbf{1 a}$ and $\mathbf{1 b}$ displayed similar $\left(42.90 \mu \mathrm{M}\right.$ and $44.91 \mu \mathrm{M}$, respectively) IC $_{50}$ values (concentration inducing 50\% apoptosis, calculated using GraphPad Prism 5.0 software, GraphPad Software Inc., San Diego, CA), whereas the shortening of the aliphatic chain (compounds $\mathbf{2 a}$ and $\mathbf{2 b}$ ) resulted in a 2-3-fold lower activity. This outcomes are consistent with the effects exerted by tested compounds on the acetylation levels of histone and non-histone proteins. None of the tested compounds 1-11 showed any significant differentiating effect (see Supplementary data).

\subsection{SPR-based binding assay}

We previously reported that $\mathbf{1 b}$ strongly inhibits (74\% of inhibition at $50 \mu \mathrm{M}$ ) immunoprecipitated KAT3A/KAT3B from U937 cell nuclear extracts. ${ }^{67}$ Thus, we resolved to ascertain if the long chain alkylidenemalonates (LoCAMs) 1-3, the most active in cellular experiments, besides KAT3A could bind also to KAT3B. To this aim, we took advantage of a surface plasmon resonance-based binding assay as implemented with Biacore technology, recently set up and successfully employed by us to study kinetic and thermodynamic parameters of ligand-protein interactions between KAT3B and a series of polyisoprenylated benzophenone derivatives. $^{55}$ This assay allowed us to assess in real time how compounds associate and dissociate from the protein and provided detailed information on the interaction. Thus, human recombinant full-length KAT3B and KAT3B catalytic domain were immobilized on different flow cells of the biosensor chip and the five LoCAMs were injected at different concentrations (from 50-200 $\mu \mathrm{M}$ ) over the protein surface; the binding of each compound was read out in real time as the change in mass at the sensor surface. After injection, running buffer was flowed over the surface and dissociation of the compounds from the surface was observed (Fig. 7). Noteworthy, three out of the five tested LoCAMs (compounds $\mathbf{2 a}, \mathbf{2 b}$, and 3) interacted efficiently with the immobilized full-length protein, as shown by the concentration-dependent responses and the clearly evident exponential curves during both the association and dissociation phases, but not with the immobilized catalytic domain (see Supplementary data). This seems to suggest an interaction with a site different from the catalytic one. On the other hand, SPR experiments carried out on compounds $\mathbf{1 a}$ and $\mathbf{1 b}$ on both proteins also produced good sensorgrams, but showed very low and/or concentration-independent responses, thus suggesting negligible interactions of such molecules with $\mathrm{p} 300$. To evaluate possible 

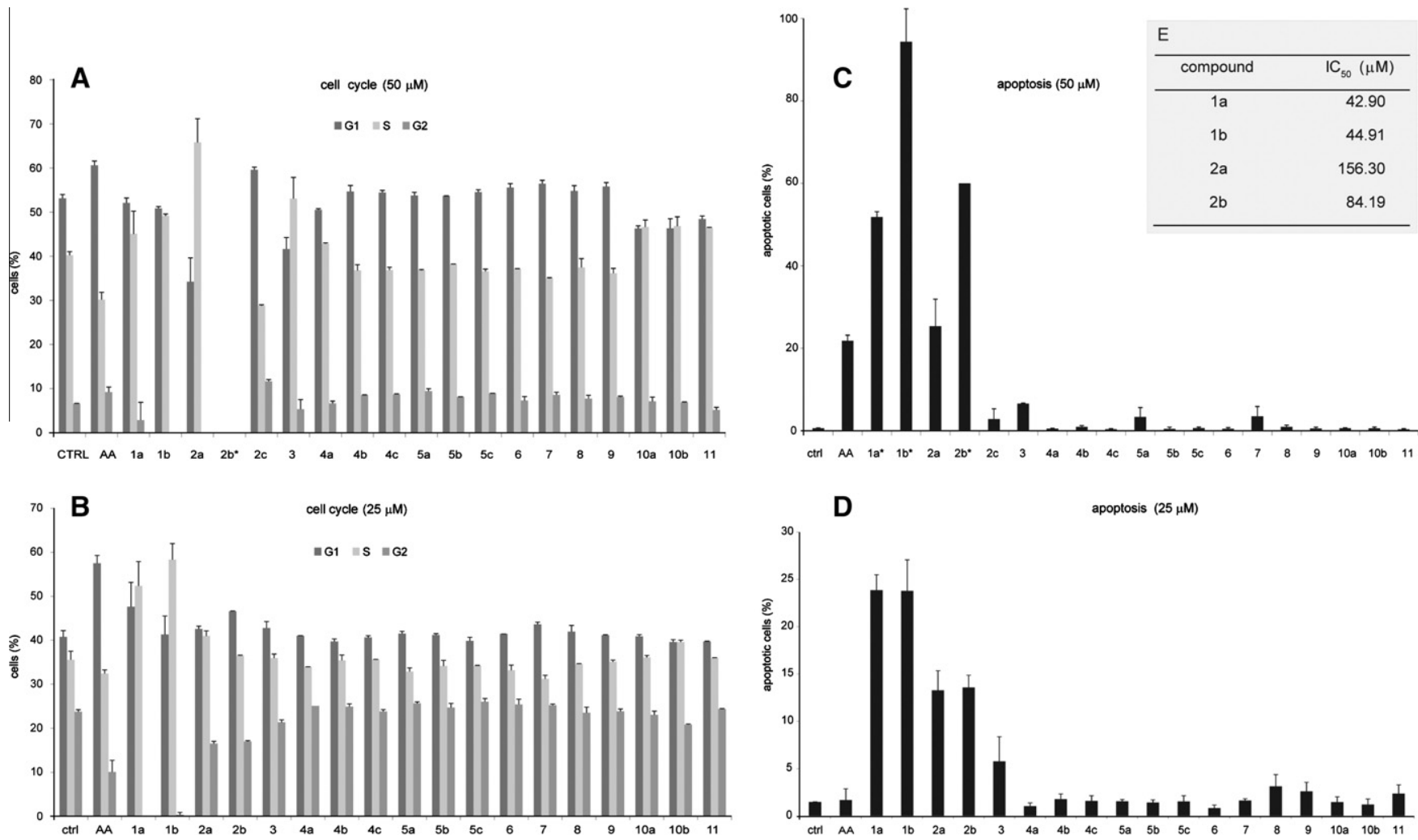

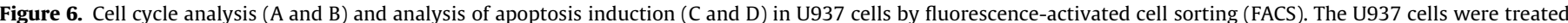

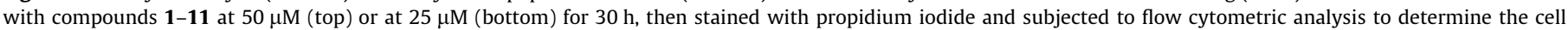

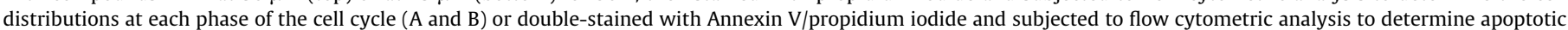

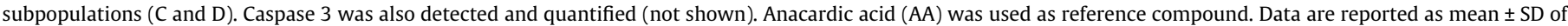

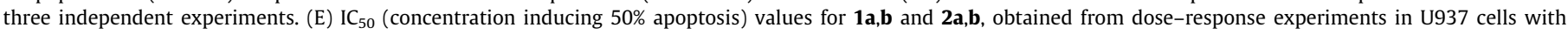
compounds tested at 5-200 $\mu \mathrm{M}$.

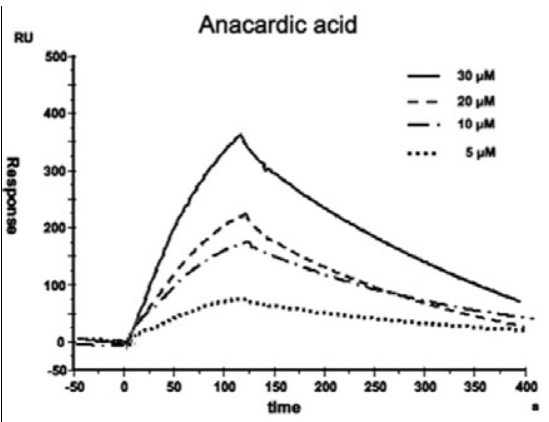

$2 a$

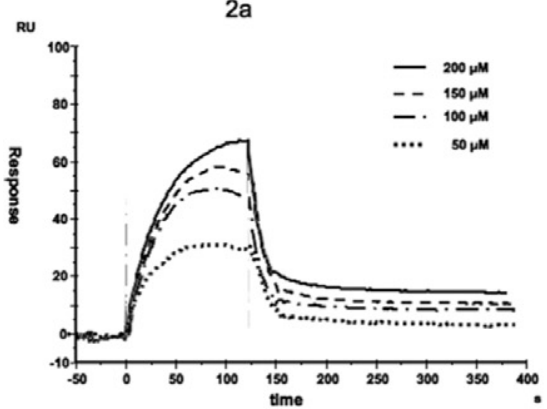

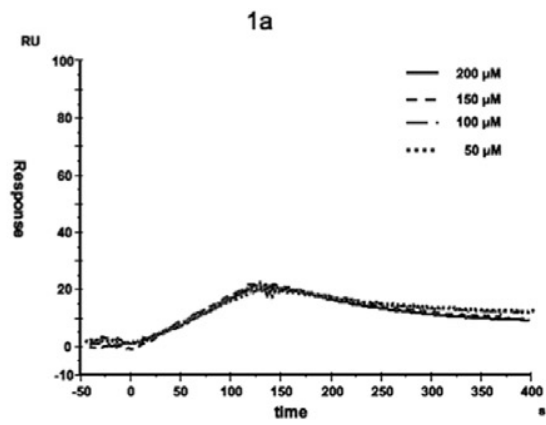

$2 \mathrm{~b}$

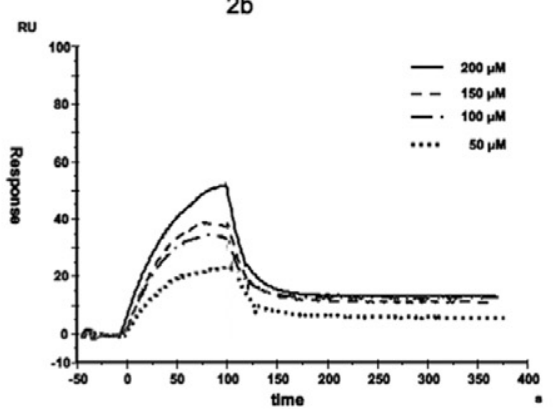

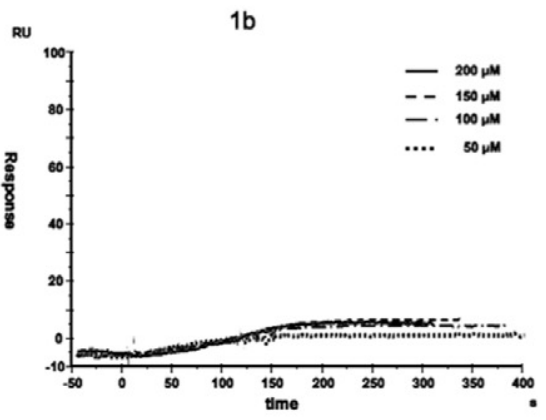

3

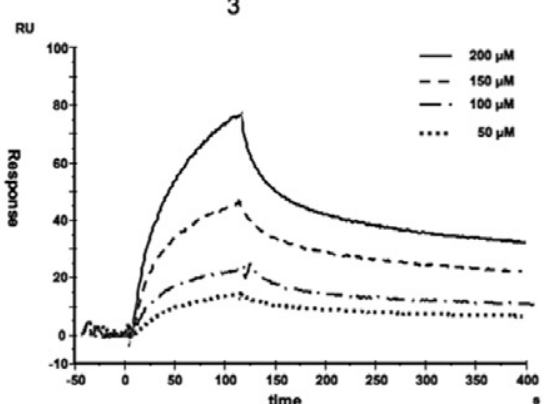

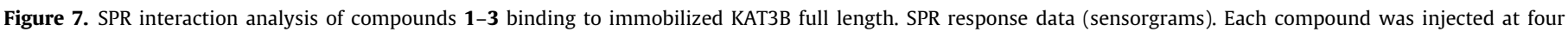
different concentrations $(50,100,150$, and $200 \mu \mathrm{M})$.

unspecific bindings, compounds 1-3 were also injected on an immobilized bovine serum albumin (BSA), and no interaction was observed (data not shown).
The outcomes of SPR experiments were consistent with the results (see Supplementary data) of fluorescence-based assays, performed to evaluate the ability of compounds 1-3 to modulate 
the acetyltransferase activity of KAT3B. As a matter of fact, all tested compounds showed negligible effects on KAT3B (both fulllength and catalytic domain) biological activity.

\subsection{Effect on the acetylation of specific lysine residues}

We next examined the effects of compounds 1-3 on the acetylation of specific lysine residues of core histones $\mathrm{H} 3$ (K9, K14, K18, K56) and H4 (K5, K8, K16). Thus, U937 cells were incubated (for $24 \mathrm{~h}$ ) with vehicle, compounds 1-3 $(50 \mu \mathrm{M})$ or with the reference compound SAHA $(5 \mu \mathrm{M})$, and the histone extracts were then immunoblotted with antibodies to specific histone acetylation sites (Fig. 8). This assay confirmed what we already observed that small differences in the length of the aliphatic side chain of LoCAM derivatives appear critical for biological activity. In fact, as shown in Figure 8, compounds $\mathbf{1 b}$ and $\mathbf{2 b}$ were able to induce hyperacetylation (in the case of $\mathbf{1 b}$ similar to that exerted by SAHA) of specific H3 lysine residues (in particular H3K9 and H3K18) as well as the level of pan-acetylated $\mathrm{H} 4$, but while $\mathbf{1 b}$ was comparable to control in all the other assays, dodecylidenemalonate $\mathbf{2 b}$ inhibited the acetylation of all the other $\mathrm{H} 3$ and $\mathrm{H} 4$ lysines, with the exception of H4K8Ac. ${ }^{75}$ On the contrary, derivatives $\mathbf{1 a}$ and, even more evidently, 2a exhibited a significant inhibition of the acetylation of almost any lysine residue explored, again with the sole exception of H4K8. Both derivatives $\mathbf{2 a}$ and $\mathbf{2} \mathbf{b}$ reduced the level of H4K5Ac and, more markedly, H4K16Ac. Tridecylidenemalonate 2c and the diketone $\mathbf{3}$ showed inhibition (at a different extent, according to the specific antibody used in the Western blots) against the acetylation of, respectively, H3K9/K18 and H3K9/K14, being practically inactive in all the other assays. None of the compounds tested exhibited a detectable effect the acetylation of H4K8.

\section{Conclusion}

In this article, we have described the synthesis of compounds 1-11 as analogues of pentadecylidenemalonate $\mathbf{1 b}$, recently reported by us as the first activator/inhibitor of histone acetyltransferases. ${ }^{67}$ With the aim to identify the effects on the biological activity of structural modifications such as length of the alkyl chain, nature of the carbonyl function, occurrence of substituents, and rigidity/flexibility of the scaffold, we tested the capability of such derivatives to modulate the acetyltransferase activity of human recombinant KAT3A and KAT2B, and assayed their effects on the acetylation of both histone- $(\mathrm{H} 3)$ and non-histone proteins (tubulin). Their effects on cell cycle, apoptosis induction, and granulocytic differentiation on U937 cells were also evaluated. In addition, we explored the binding capability of selected compounds to KAT3B, using both the full length protein and the catalytic domain in a SPR-based assay, and their effects on the acetylation of specific histonic lysine residues, by immunoblotting histone extracts with specific antibodies.

Taken together, the data resulting from biological assays showed that, in general, major modifications introduced in the
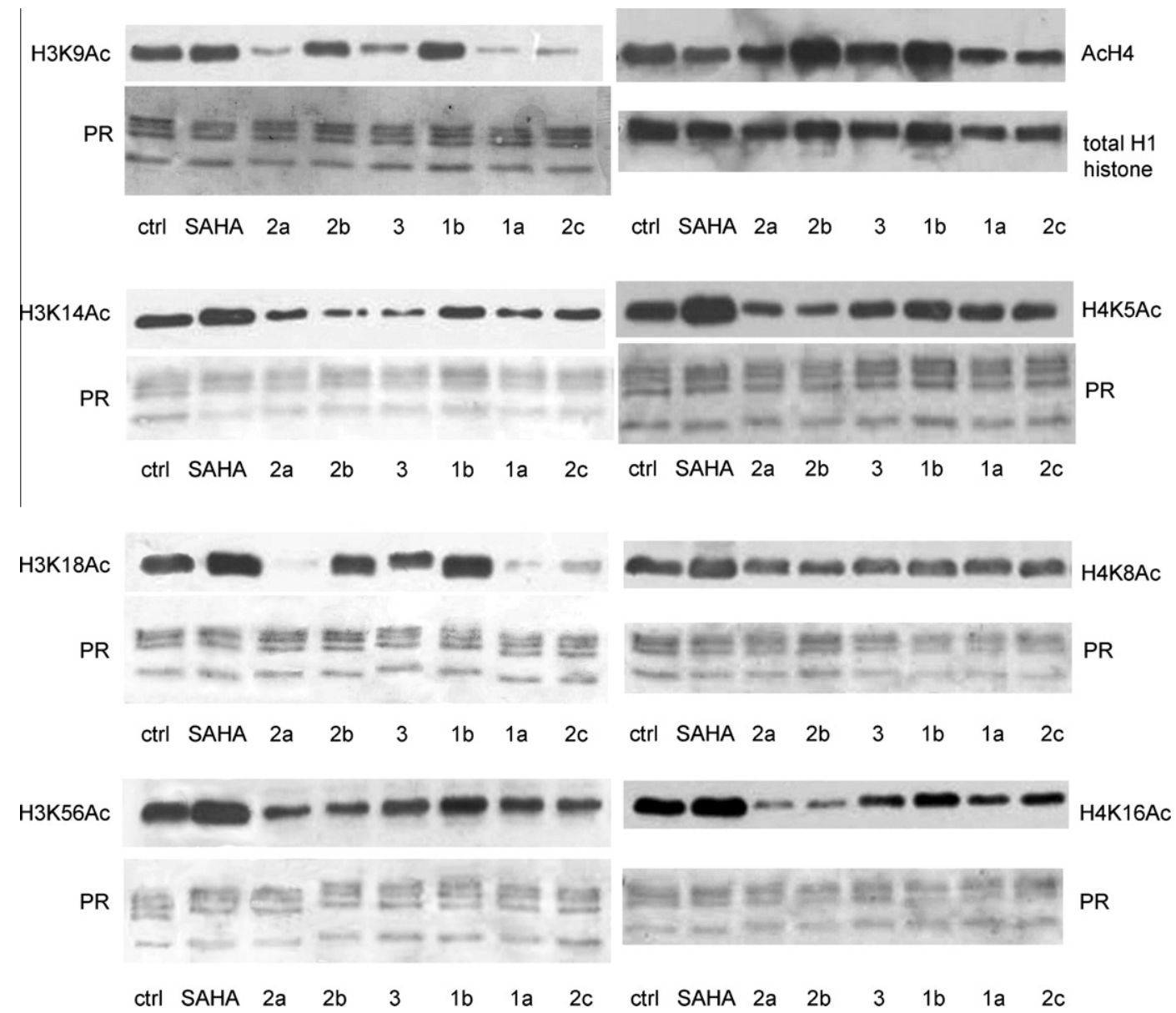

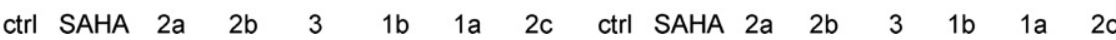

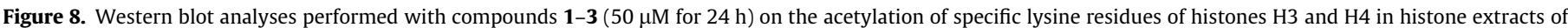

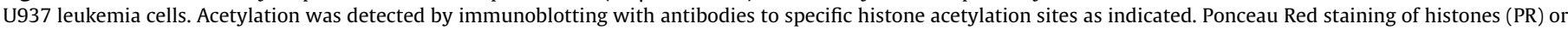
total $\mathrm{H} 1$ histone (in the case of pan-acH4) were used to check for equal loading. SAHA (5 $\mu \mathrm{M}$ ) was used as reference compound. 
alkylidenemalonate scaffold were detrimental for the activity of the resulting compounds. In fact, only the variation of alkyl chain length (derivatives 1a and $\mathbf{2 a - c}$ ) or the substitution of ester functions with keto groups (derivative 3 ) yielded compounds displaying a strong inhibition against recombinant KAT3A (in the range $79-83 \%)$, thereby being more powerful than AA (62\% of inhibition at $50 \mu \mathrm{M}$ ) in this assay. On the other hand, only compound 1a, its inferior homologue, was comparable to $\mathbf{1 b}$ in the activation of the enzymatic activity of KAT2B, whereas the shorter malonates 2a-c were inactive or displayed just a moderate inhibition. Accordingly, western blot analyses showed that, similarly to $\mathbf{1 b}$, compound $\mathbf{1 a}$ was able to induce hyperacetylation of $\mathrm{H} 3$ in U937 cells, without affecting tubulin acetylation (in MCF7 cells). On the contrary, derivatives $\mathbf{2 a}$ and $\mathbf{2 b}$ and, to a lesser extent, derivative $\mathbf{3}$ induced a significant hypoacetylation of the $\mathrm{H} 3$ histone substrate in the same conditions. The effects of tested compounds on cell cycle and apoptosis induction evidenced again that the shortening of the aliphatic chain (compounds $\mathbf{2 a}$ and $\mathbf{2 b}$ ) resulted in a 2-3-fold lower activity, while compounds $\mathbf{1 a}$ and $\mathbf{1 b}$ displayed similar $(42.90 \mu \mathrm{M}$ and $44.91 \mu \mathrm{M}$, respectively) concentration inducing $50 \%$ apoptosis $\left(\mathrm{IC}_{50}\right)$ values. Interestingly, SPR-based assays showed that the long chain alkylidenemalonates (LoCAMs) 2a and $\mathbf{2 b}$ as well as the diketone $\mathbf{3}$ were able to interact with p300 full-length but not with the catalytic domain, whereas just negligible interactions were recorded for both $\mathbf{1 a}$ and $\mathbf{1 b}$. It is noteworthy that Giannis and co-workers previously reported that the length of the aliphatic side chain seems crucial for biological activity of analogues of MB-3. ${ }^{65} \mathrm{~A}$ few other derivatives exhibited various degrees of activity in one or both the enzymatic assays, but were practically inactive in cellular assays.

In summary, we have identified LoCAMs as a novel, interesting class of KAT modulators. Variations of the alkyl chain length can change their activity profile from KAT3A/KAT2B inhibitors (as derivative $\mathbf{2 a}$ ) to the peculiar profile of pentadecylidenemalonate 1b, the first activator/inhibitor of histone acetyltransferases. Together with the powerful apoptotic effect (particularly notable if considering that anacardic acid and other KAT inhibitors are not cell permeable) appoint them as valuable biological tools to understand the mechanisms of lysine acetyltransferases. Further biological in vitro and in vivo studies are in progress to better characterize the observed properties of LoCAMs and to correlate the effects on the acetylation of specific lysine residues with the expression of particular genes. This may also prelude to a novel group of compounds for antineoplastic therapeutics.

\section{Experimental section}

\subsection{Chemistry}

All chemicals were purchased from Aldrich Chimica (Milan, Italy) or from Alfa Aesar GmbH (Karlsruhe, Germany) and were of the highest purity. All solvents were reagent grade and, when necessary, were purified and dried by standard methods. A sample of suberoylanilide hydroxamic acid (SAHA) for biological assays was prepared as previously reported by us. ${ }^{76}$ All reactions requiring anhydrous conditions were conducted under a positive atmosphere of nitrogen in oven-dried glassware. Standard syringe techniques were used for anhydrous addition of liquids. Reactions were routinely monitored by TLC performed on aluminum-backed silica gel plates (Merck DC, Alufolien Kieselgel $60 \mathrm{~F}_{254}$ ) with spots visualized by UV light $\left(\lambda=254,365 \mathrm{~nm}\right.$ ) or using a $\mathrm{KMnO}_{4}$ alkaline solution. Concentration of solutions after reactions and extractions involved the use of a rotary evaporator operating at a reduced pressure of $\sim 10$ Torr. Organic solutions were dried over anhydrous sodium sulfate. Chromatographic separations were performed on silica gel (Silica Gel 60, 0.063-0.200 mm; Merck DC) columns.
Melting points were determined on a Gallenkamp melting point apparatus in open capillary tubes and are uncorrected. ${ }^{1} \mathrm{H}$ NMR spectra were recorded at $300 \mathrm{MHz}$ on a Bruker Avance $300 \mathrm{spec}-$ trometer; chemical shifts are reported in $\delta$ (ppm) units relative to the internal reference tetramethylsilane $\left(\mathrm{Me}_{4} \mathrm{Si}\right)$. Mass spectra were recorded on a Finnigan LCQ DECA TermoQuest (San Jose, CA, USA) mass spectrometer using an electrospray ion source (ESI-MS). Combustion analysis on target compounds was performed by our Analytical Laboratory at the University of Salerno. All compounds showed $\geqslant 98 \%$ purity. When the elemental analysis is not included, crude compounds were used in the next step without further purification. As a rule, samples prepared for physical and biological studies were dried in high vacuum over $\mathrm{P}_{2} \mathrm{O}_{5}$ for $20 \mathrm{~h}$ at temperatures ranging from 25 to $110^{\circ} \mathrm{C}$, depending on the sample melting point.

\subsubsection{General procedure for the synthesis of aldehydes 12a,b. Example: tetradecanal (12a) ${ }^{67,77}$}

To a solution of commercial tetradecan-1-ol $(0.72 \mathrm{~g}, 3.37 \mathrm{mmol})$ in DCM $(20 \mathrm{~mL})$ at $0{ }^{\circ} \mathrm{C}$ Dess-Martin periodinane (DMP) $(1.53 \mathrm{~g}$, $3.60 \mathrm{mmol}$ ) was added. After completion ( $45 \mathrm{~min}$, TLC monitoring), the reaction crude was directly purified by column chromatography (silica gel, $\mathrm{CHCl}_{3} / n$-hexane, $3: 1$ ) to afford the required aldehyde as a waxy white solid (187 $\mathrm{mg}, 98 \%$ yield). ${ }^{1} \mathrm{H}$ NMR $\left(\mathrm{CDCl}_{3}\right)$ : $\delta 0.88\left(\mathrm{t}, 3 \mathrm{H}, \mathrm{CH}_{3}\right), 1.26-1.29\left(\mathrm{~m}, 20 \mathrm{H}, 10 \times \mathrm{CH}_{2}\right), 1.60-1.65(\mathrm{~m}$, $\left.2 \mathrm{H}, \mathrm{CH}_{2}\right), 2.40-2.50\left(\mathrm{~m}, 2 \mathrm{H}, \mathrm{CH}_{2}\right), 9.77(\mathrm{t}, 1 \mathrm{H}, \mathrm{H}-1)$; MS (EI, $\left.70 \mathrm{eV}\right)$ $m / z(\%): 212$.

Pentadecanal $\mathbf{1 2 b},{ }^{78}$ was obtained following the same procedure starting from commercial pentadecan-1-ol. ${ }^{1} \mathrm{H}$ NMR $\left(\mathrm{CDCl}_{3}\right)$ : $\delta 0.86\left(\mathrm{t}, 3 \mathrm{H}, \mathrm{CH}_{3}\right), 1.26-1.30\left(\mathrm{~m}, 22 \mathrm{H}, 11 \times \mathrm{CH}_{2}\right), 1.59-1.64(\mathrm{~m}$, $\left.2 \mathrm{H}, \mathrm{CH}_{2}\right), 2.38-2.50\left(\mathrm{~m}, 2 \mathrm{H}, \mathrm{CH}_{2}\right), 9.87(\mathrm{t}, 1 \mathrm{H}, \mathrm{H}-1)$; MS (EI, $\left.70 \mathrm{eV}\right)$ $m / z$ (\%): 226 .

\subsubsection{General procedure for the synthesis of derivatives 1-3. Example: diethyl 2-tetradecylidenemalonate $(1 \mathrm{a})^{67}$}

A stirred solution of the aldehyde $\mathbf{1 2 a}(3.98 \mathrm{mmol})$ and diethyl malonate $(4.38 \mathrm{mmol})$ in anhydrous methylene chloride $(3 \mathrm{~mL})$ was treated with piperidine $(0.08 \mathrm{mmol})$ and acetic acid $(0.08 \mathrm{mmol})$ at $0{ }^{\circ} \mathrm{C}$. After $45 \mathrm{~min}$ of stirring, a small amount of 3 - $\AA$ molecular sieves was added. Then the reaction mixture was stirred at room temperature for another $15 \mathrm{~min}$ (TLC monitoring), diluted with diethyl ether $(50 \mathrm{~mL})$, and washed with water $(10 \mathrm{~mL})$ until the aqueous phase was neutral. The collected aqueous phases were extracted with diethyl ether $(3 \times 10 \mathrm{~mL})$. The combined etheral phases were successively washed with saturated sodium hydrogen carbonate solution $(3 \times 10 \mathrm{~mL})$ and brine $(3 \times 10 \mathrm{~mL})$ and dried $\left(\mathrm{Na}_{2} \mathrm{SO}_{4}\right)$. After removing the solvent, the crude was purified by column chromatography $\left(\mathrm{SiO}_{2}, n\right.$-hexane/AcOEt $\left.8: 2\right)$ to obtain compound 1a as an oil, in a $83 \%$ yield. ${ }^{1} \mathrm{H}$ NMR $\left(\mathrm{CDCl}_{3}\right): \delta 0.90$ $\left(\mathrm{t}, 3 \mathrm{H}, \mathrm{CH}_{3}\right), 1.27-1.36\left(\mathrm{~m}, 26 \mathrm{H}, 10 \times \mathrm{CH}_{2}\right.$ and $2 \times \mathrm{OCH}_{2} \mathrm{CH}_{3}$, overlapped signals), 1.47-1.51 (m, $\left.2 \mathrm{H}, \mathrm{CH}_{2} \mathrm{CH}_{2} \mathrm{C}=\right), 2.28-2.33(\mathrm{~m}, 2 \mathrm{H}$, $\mathrm{CH}_{2} \mathrm{C}=$ ), 4.23-4.34 (dm, $4 \mathrm{H}, 2 \times \mathrm{OCH}_{2} \mathrm{CH}_{3}$, overlapped signals), $7.02(\mathrm{t}, 1 \mathrm{H}, \mathrm{CH})$; MS (EI, $70 \mathrm{eV}) \mathrm{m} / \mathrm{z}(\%)$ : 354. Anal. Calcd for $\mathrm{C}_{21} \mathrm{H}_{38} \mathrm{O}_{4}$ (354.52): C, 71.14; H, 10.80. Found: C, 71.07; H, 10.79.

Diethyl 2-pentadecylidenemalonate $\mathbf{1 b},{ }^{67}$ 2-undecylmalonate 2a, 2-dodecylmalonate $\mathbf{2 b}$, and 2-tridecylmalonate $\mathbf{2 c}$ were obtained following the same procedure starting, respectively, from pentadecanal (12b), undecanal, dodecanal (lauric aldehyde), and tridecanal. 3-pentadecylidenepentane-2,4-dione 3 was prepared following the same procedure starting from 2,4-pentanedione (acetylacetone) and pentadecanal 12b.

Compound 1b: oil (yield 86\%); ${ }^{1} \mathrm{H}$ NMR $\left(\mathrm{CDCl}_{3}\right): \delta 0.90(\mathrm{t}, 3 \mathrm{H}$, $\left.\mathrm{CH}_{3}\right), 1.27-1.36\left(\mathrm{~m}, 28 \mathrm{H}, 11 \times \mathrm{CH}_{2}\right.$ and $2 \times \mathrm{OCH}_{2} \mathrm{CH}_{3}$, overlapped signals), $1.48-1.58\left(\mathrm{~m}, 2 \mathrm{H}, \mathrm{CH}_{2} \mathrm{CH}_{2} \mathrm{C}=\right)$, 2.29-2.33 ( $\left.\mathrm{m}, 2 \mathrm{H}, \mathrm{CH}_{2} \mathrm{C}=\right)$, 4.24-4.34 (dm, $4 \mathrm{H}, 2 \times \mathrm{OCH}_{2} \mathrm{CH}_{3}$, overlapped signals), $7.02(\mathrm{t}, 1 \mathrm{H}$, 
$\mathrm{CH}$ ); MS (EI, $70 \mathrm{eV}) \mathrm{m} / z$ (\%): 368. Anal. Calcd for $\mathrm{C}_{22} \mathrm{H}_{40} \mathrm{O}_{4}$ (368.29): C, 71.70; H, 10.94. Found: C, 71.63; H, 10.93 .

Compound 2a: oil (yield 87\%); ${ }^{1} \mathrm{H}$ NMR $\left(\mathrm{CDCl}_{3}\right): \delta 0.88(\mathrm{t}, 3 \mathrm{H}$, $\left.\mathrm{CH}_{3}\right), 1.25-1.35\left(\mathrm{~m}, 2 \mathrm{OH}, 7 \times \mathrm{CH}_{2}\right.$ and $2 \times \mathrm{OCH}_{2} \mathrm{CH}_{3}$, overlapped signals), $1.47\left(\mathrm{~m}, 2 \mathrm{H}, \mathrm{CH}_{2} \mathrm{CH}_{2} \mathrm{C}=\right), 2.27-2.30\left(\mathrm{~m}, 2 \mathrm{H}, \mathrm{CH}_{2} \mathrm{C}=\right)$, 4.20-4.31 (dm, $4 \mathrm{H}, 2 \times \mathrm{OCH}_{2} \mathrm{CH}_{3}$, overlapped signals), $7.00(\mathrm{t}, 1 \mathrm{H}$, $\mathrm{CH}$ ); $\mathrm{MS}$ (EI, $70 \mathrm{eV}) \mathrm{m} / z$ (\%): 312. Anal. Calcd for $\mathrm{C}_{18} \mathrm{H}_{32} \mathrm{O}_{4}$ (312.23): C, 69.19; H, 10.32. Found: C, 69.01; H, 10.30.

Compound 2b: oil (yield 85\%); ${ }^{1} \mathrm{H}$ NMR $\left(\mathrm{CDCl}_{3}\right): \delta 0.88(\mathrm{t}, 3 \mathrm{H}$, $\left.\mathrm{CH}_{3}\right), 1.25-1.35\left(\mathrm{~m}, 22 \mathrm{H}, 8 \times \mathrm{CH}_{2}\right.$ and $2 \times \mathrm{OCH}_{2} \mathrm{CH}_{3}$, overlapped signals), $1.47\left(\mathrm{~m}, 2 \mathrm{H}, \mathrm{CH}_{2} \mathrm{CH}_{2} \mathrm{C}=\right), 2.27-2.30\left(\mathrm{~m}, 2 \mathrm{H}, \mathrm{CH}_{2} \mathrm{C}=\right)$, 4.22-4.31 (dm, $4 \mathrm{H}, 2 \times \mathrm{OCH}_{2} \mathrm{CH}_{3}$, overlapped signals), $7.00(\mathrm{t}, 1 \mathrm{H}$, $\mathrm{CH}$ ); MS (EI, $70 \mathrm{eV}) \mathrm{m} / z$ (\%): 326. Anal. Calcd for $\mathrm{C}_{19} \mathrm{H}_{34} \mathrm{O}_{4}$ (326.25): C, 69.90; H, 10.50. Found: C, 69.77; H, 10.48 .

Compound 2c: oil (yield 88\%); ${ }^{1} \mathrm{H}$ NMR $\left(\mathrm{CDCl}_{3}\right): \delta 0.88(\mathrm{t}, 3 \mathrm{H}$, $\left.\mathrm{CH}_{3}\right), 1.25-1.35\left(\mathrm{~m}, 24 \mathrm{H}, 9 \times \mathrm{CH}_{2}\right.$ and $2 \times \mathrm{OCH}_{2} \mathrm{CH}_{3}$, overlapped signals), $1.47\left(\mathrm{~m}, 2 \mathrm{H}, \mathrm{CH}_{2} \mathrm{CH}_{2} \mathrm{C}=\right), 2.25-2.32\left(\mathrm{~m}, 2 \mathrm{H}, \mathrm{CH}_{2} \mathrm{C}=\right)$, 4.20-4.33 (dm, $4 \mathrm{H}, 2 \times \mathrm{OCH}_{2} \mathrm{CH}_{3}$, overlapped signals), $6.99(\mathrm{t}, 1 \mathrm{H}$, $\mathrm{CH}$ ); $\mathrm{MS}$ (EI, $70 \mathrm{eV}) \mathrm{m} / \mathrm{z}$ (\%): 340. Anal. Calcd for $\mathrm{C}_{20} \mathrm{H}_{36} \mathrm{O}_{4}$ (340.26): C, 70.55; H, 10.66. Found: C, 70.41; H, 10.64.

Compound 3: oil (yield 83\%); ${ }^{1} \mathrm{H}$ NMR $\left(\mathrm{CDCl}_{3}\right): \delta 0.90(\mathrm{t}, 3 \mathrm{H}$, $\left.\mathrm{CH}_{3}\right), 1.26-1.38\left(\mathrm{~m}, 22 \mathrm{H}, 11 \times \mathrm{CH}_{2}\right), 1.51\left(\mathrm{~m}, 2 \mathrm{H}, \mathrm{CH}_{2} \mathrm{CH}_{2} \mathrm{C}=\right)$, 2.23-2.28(m, $\left.2 \mathrm{H}, \mathrm{CH}_{2} \mathrm{C}=\right), 2.34\left(\mathrm{~s}, 6 \mathrm{H}, 2 \times \mathrm{COCH}_{3}\right), 6.70(\mathrm{t}, 1 \mathrm{H}$, $\mathrm{CH}$ ); MS (EI, $70 \mathrm{eV}) \mathrm{m} / \mathrm{z}$ (\%): 308. Anal. Calcd for $\mathrm{C}_{20} \mathrm{H}_{36} \mathrm{O}_{2}$ (308.27): C, 77.87; H, 11.76. Found: C, 77.69; H, 11.74.

\subsubsection{General procedure for the synthesis of alkylmalonates $4 a-c$}

Diethyl 2-tridecylmalonate $\mathbf{4 a},{ }^{71}$ tetradecylmalonate $\mathbf{4 b},{ }^{69}$ and pentadecylmalonate $\mathbf{4} c^{70}$ were prepared as previously reported ${ }^{69}$ from diethyl malonate and, respectively, tridecyl-, tetradecyl-, and pentadecylbromide.

Compound 4a: oil (yield 75\%); ${ }^{1} \mathrm{H}$ NMR $\left(\mathrm{CDCl}_{3}\right): \delta 0.88(\mathrm{t}, 3 \mathrm{H}$, $\left.\mathrm{CH}_{3}\right), 1.27-1.41\left(\mathrm{~m}, 28 \mathrm{H}, 11 \times \mathrm{CH}_{2}\right.$ and $2 \times \mathrm{OCH}_{2} \mathrm{CH}_{3}$, overlapped signals), $1.75-1.80\left(\mathrm{~m}, 2 \mathrm{H},-\mathrm{CH}_{2} \mathrm{CH}-\right), 3.28-3.34\left(\mathrm{t}, 1 \mathrm{H},-\mathrm{CH}_{2} \mathrm{CH}-\right)$, 4.12-4.18 (q, 4H, $2 \times \mathrm{OCH}_{2} \mathrm{CH}_{3}$ ); $\mathrm{MS}$ (EI, $70 \mathrm{eV}$ ) m/z (\%): 342. Anal. Calcd for $\mathrm{C}_{20} \mathrm{H}_{38} \mathrm{O}_{4}$ (342.28): C, 70.13; $\mathrm{H}, 11.18$. Found: C, 70.06; $\mathrm{H}, 11.17$.

Compound 4b: oil (yield 71\%); ${ }^{1} \mathrm{HNMR}\left(\mathrm{CDCl}_{3}\right): \delta 0.88\left(\mathrm{t}, 3 \mathrm{H}, \mathrm{CH}_{3}\right)$, $1.26-1.40\left(\mathrm{~m}, 30 \mathrm{H}, 12 \times \mathrm{CH}_{2}\right.$ and $2 \times \mathrm{OCH}_{2} \mathrm{CH}_{3}$, overlapped signals $)$, 1.76-1.81 (m, $\left.2 \mathrm{H},-\mathrm{CH}_{2} \mathrm{CH}-\right), 3.28-3.34\left(\mathrm{t}, 1 \mathrm{H},-\mathrm{CH}_{2} \mathrm{CH}-\right), 4.12-4.18$ (q, $4 \mathrm{H}, 2 \times \mathrm{OCH}_{2} \mathrm{CH}_{3}$ ); MS (EI, $\left.70 \mathrm{eV}\right) \mathrm{m} / z$ (\%): 356. Anal. Calcd for $\mathrm{C}_{21} \mathrm{H}_{40} \mathrm{O}_{4}$ (356.29): C, 70.74; $\mathrm{H}, 11.31$. Found: C, 70.58; $\mathrm{H}, 11.29$.

Compound 4c: oil (yield 72\%); ${ }^{1} \mathrm{H}$ NMR $\left(\mathrm{CDCl}_{3}\right): \delta 0.89(\mathrm{t}, 3 \mathrm{H}$, $\left.\mathrm{CH}_{3}\right), 1.26-1.42\left(\mathrm{~m}, 32 \mathrm{H}, 13 \times \mathrm{CH}_{2}\right.$ and $2 \times \mathrm{OCH}_{2} \mathrm{CH}_{3}$, overlapped signals), $1.76-1.81\left(\mathrm{~m}, 2 \mathrm{H},-\mathrm{CH}_{2} \mathrm{CH}-\right), 3.27-3.33\left(\mathrm{t}, 1 \mathrm{H},-\mathrm{CH}_{2} \mathrm{CH}-\right)$, 4.13-4.19 (q, 4H, $2 \times \mathrm{OCH}_{2} \mathrm{CH}_{3}$ ); $\mathrm{MS}$ (EI, $70 \mathrm{eV}$ ) m/z (\%): 370. Anal. Calcd for $\mathrm{C}_{22} \mathrm{H}_{42} \mathrm{O}_{4}$ (370.31): C, 71.31; $\mathrm{H}, 11.42$. Found: C, 71.15; $\mathrm{H}, 11.39$.

\subsubsection{General procedure for the synthesis of derivatives $5 a-c$. Example: diethyl 2-(1-hydroxyhexadecylidene)malonate $5 b^{\mathbf{6 7}}$}

Triethylamine $(1.30 \mathrm{~mL}, 9.36 \mathrm{mmol})$ and magnesium chloride $(0.71 \mathrm{~g}, 7.49 \mathrm{mmol})$ were added to a stirred solution of diethyl malonate $(1.00 \mathrm{~g}, 6.24 \mathrm{mmol})$ in dry acetonitrile $(20 \mathrm{~mL})$ while cooling at $0{ }^{\circ} \mathrm{C}$. The mixture was stirred at room temperature for $2 \mathrm{~h}$. Then a previously prepared mixture of palmitic acid $(1.60 \mathrm{~g}, 6.24 \mathrm{mmol})$ and $N, N^{\prime}$-carbonyldiimidazole $(1.11 \mathrm{~g}, 6.87 \mathrm{mmol})$ in dry acetonitrile $(15 \mathrm{~mL})$ was added, and the resulting slurry was stirred overnight. After completion (TLC monitoring, $\mathrm{SiO}_{2} / \mathrm{CHCl}_{3}$ ), the mixture was cautiously acidified with $13 \% \mathrm{HCl}$ while keeping the temperature below $25^{\circ} \mathrm{C}$, and the resulting mixture was stirred for additional $15 \mathrm{~min}$. The organic layer was separated and evaporated, and the residue was treated with ethyl acetate $(20 \mathrm{~mL})$. The aqueous layer was extracted with ethyl acetate $(2 \times 20 \mathrm{~mL})$, and the organic phases were combined, washed with saturated sodium bicarbonate solution $(2 \times 30 \mathrm{~mL})$ and brine $(3 \times 30 \mathrm{~mL})$, dried and concentrated to give the crude diethyl 2-(1-hydroxyhexadecylidene)malonates which was purified by column chromatography $\left(\mathrm{SiO}_{2}, \mathrm{CHCl}_{3}\right)$ to obtain compound $\mathbf{5 b}$ as a white solid (mp: $\left.32-33{ }^{\circ} \mathrm{C}\right)$ in a $90 \%$ yield. ${ }^{1} \mathrm{H}$ NMR $\left(\mathrm{CDCl}_{3}\right) \delta 0.88\left(\mathrm{t}, 3 \mathrm{H}, \mathrm{CH}_{3}\right)$ 1.29-1.34 $\left(\mathrm{m}, 30 \mathrm{H}, \quad 12 \times \mathrm{CH}_{2}\right.$ and $2 \times \mathrm{OCH}_{2} \mathrm{CH}_{3}$, overlapped signals), $1.57-1.62\left(\mathrm{~m}, 2 \mathrm{H}, \mathrm{CH}_{2} \mathrm{CH}_{2} \mathrm{C}(\mathrm{OH})=\right), 2.40-2.45(\mathrm{~m}, 1 \mathrm{H}$, $\left.\mathrm{CH}_{2} \mathrm{CHH}_{A} \mathrm{C}(\mathrm{OH})=\right), \quad 2.58-2.63 \quad\left(\mathrm{~m}, \quad 1 \mathrm{H}, \quad \mathrm{CH}_{2} \mathrm{CH} H_{B} \mathrm{C}(\mathrm{OH})=\right)$, 4.21-4.30 (m, $\left.4 \mathrm{H}, 2 \times \mathrm{OCH}_{2} \mathrm{CH}_{3}\right), 13.41(\mathrm{~s}, 1 \mathrm{H}, \mathrm{OH}$, exchangeable with $\mathrm{D}_{2} \mathrm{O}$ ). MS (EI, $\left.70 \mathrm{eV}\right) \mathrm{m} / z$ (\%): 398. Anal. Calcd for $\mathrm{C}_{23} \mathrm{H}_{42} \mathrm{O}_{5}$ (398.30): C, 69.31; H, 10.62. Found: C, 69.18; H, 10.60.

Diethyl 2-(1-hydroxypentadecylidene)malonate 5a and diethyl 2-(1-hydroxyheptadecylidene)malonates $\mathbf{5 c}$ were obtained following the same procedure starting from diethyl malonates and, respectively, pentadecanoic acid and heptadecanoic (margaric) acid.

Compound 5a: oil (yield 93\%). ${ }^{1} \mathrm{H}$ NMR $\left(\mathrm{CDCl}_{3}\right) \delta 0.88(\mathrm{t}, 3 \mathrm{H}$, $\left.\mathrm{CH}_{3}\right), 1.28-1.33\left(\mathrm{~m}, 28 \mathrm{H}, 11 \times \mathrm{CH}_{2}\right.$ and $2 \times \mathrm{OCH}_{2} \mathrm{CH}_{3}$, overlapped signals), $\quad 1.58-1.63 \quad\left(\mathrm{~m}, \quad 2 \mathrm{H}, \quad \mathrm{CH}_{2} \mathrm{CH}_{2} \mathrm{C}(\mathrm{OH})=\right), \quad 2.40-2.45$ $\left(\mathrm{m}, 1 \mathrm{H}, \mathrm{CH}_{2} \mathrm{CHH}_{A} \mathrm{C}(\mathrm{OH})=\right), 2.58-2.63\left(\mathrm{~m}, 1 \mathrm{H}, \mathrm{CH}_{2} \mathrm{CHH}_{B} \mathrm{C}(\mathrm{OH})=\right)$, 4.21-4.30 (m, $\left.4 \mathrm{H}, 2 \times \mathrm{OCH}_{2} \mathrm{CH}_{3}\right), 13.41(\mathrm{~s}, 1 \mathrm{H}, \mathrm{OH}$, exchangeable with $\mathrm{D}_{2} \mathrm{O}$ ). MS (EI, $\left.70 \mathrm{eV}\right) \mathrm{m} / \mathrm{z}(\%)$ : 384. Anal. Calcd for $\mathrm{C}_{20} \mathrm{H}_{40} \mathrm{O}_{5}$ (384.29): C, 68.71; H, 10.48. Found: C, 68.56; H, 10.46.

Compound 5c: oil (yield 91\%). ${ }^{1} \mathrm{H}$ NMR $\left(\mathrm{CDCl}_{3}\right) \delta 0.89(\mathrm{t}, 3 \mathrm{H}$, $\left.\mathrm{CH}_{3}\right), 1.29-1.32\left(\mathrm{~m}, 32 \mathrm{H}, 13 \times \mathrm{CH}_{2}\right.$ and $2 \times \mathrm{OCH}_{2} \mathrm{CH}_{3}$, overlapped signals), $\quad 1.57-1.62 \quad\left(\mathrm{~m}, \quad 2 \mathrm{H}, \quad \mathrm{CH}_{2} \mathrm{CH}_{2} \mathrm{C}(\mathrm{OH})=\right), \quad 2.40-2.45$ $\left(\mathrm{m}, 1 \mathrm{H}, \mathrm{CH}_{2} \mathrm{CHH}_{A} \mathrm{C}(\mathrm{OH})=\right), 2.58-2.63\left(\mathrm{~m}, 1 \mathrm{H}, \mathrm{CH}_{2} \mathrm{CHH}_{B} \mathrm{C}(\mathrm{OH})=\right)$, 4.21-4.30 (m, $\left.4 \mathrm{H}, 2 \times \mathrm{OCH}_{2} \mathrm{CH}_{3}\right), 13.41(\mathrm{~s}, 1 \mathrm{H}, \mathrm{OH}$, exchangeable with $\mathrm{D}_{2} \mathrm{O}$ ). MS (EI, $\left.70 \mathrm{eV}\right) \mathrm{m} / z$ (\%): 412. Anal. Calcd for $\mathrm{C}_{24} \mathrm{H}_{44} \mathrm{O}_{5}$ (412.32): C, 69.86; H, 10.75. Found: C, 69.72; H, 10.73 .

\subsubsection{Preparation of diethyl 2-(1-chloropentadecylidene)- malonate 6}

A solution of compound $\mathbf{5 a}(2.16 \mathrm{~g}, 5.62 \mathrm{mmol})$ in phospho$\operatorname{rus}(\mathrm{V})$ oxychloride $(4.79 \mathrm{~g}, 31.22 \mathrm{mmol})$ was cooled to $0{ }^{\circ} \mathrm{C}$ then treated with triethylamine $(0.87 \mathrm{~mL}, 6.24 \mathrm{mmol})$ dropwise. The resulting mixture was stirred at room temperature overnight then heated to $80{ }^{\circ} \mathrm{C}$ for additional $4 \mathrm{~h}$. After completion (TLC monitoring, $\mathrm{SiO}_{2}, \mathrm{CHCl}_{3} / n$-hexane 3:1), the mixture was evaporated and the brownish residue was treated with saturated sodium carbonate solution $(30 \mathrm{~mL})$ and extracted with petroleum ether $(3 \times 15 \mathrm{~mL})$. The organic phases were combined, washed with saturated sodium bicarbonate solution $(3 \times 10 \mathrm{~mL})$ and brine $(3 \times 30 \mathrm{~mL})$, dried, and evaporated and the residue was purified by column chromatography (silica gel, $\mathrm{CHCl}_{3} / n$-hexane $1: 1$ ) to give the required ester $\mathbf{6}$ as a pale yellow oil (yield: 80\%). MS (EI, $70 \mathrm{eV}$ ) m/z: 402 (100.0\%), 404 (35.6\%). ${ }^{1} \mathrm{H}$ NMR $\left(\mathrm{CDCl}_{3}\right) \delta 0.88\left(\mathrm{t}, 3 \mathrm{H}, \mathrm{CH}_{3}\right), 1.26-1.34(\mathrm{~m}, 28 \mathrm{H}$, $11 \times \mathrm{CH}_{2}$ and $2 \times \mathrm{OCH}_{2} \mathrm{CH}_{3}$, overlapped signals), $1.66(\mathrm{~m}, 2 \mathrm{H}$, $\left.\mathrm{CH}_{2} \mathrm{CH}_{2} \mathrm{C}=\right), 2.89-2.94\left(\mathrm{t}, 2 \mathrm{H}, \mathrm{CH}_{2} \mathrm{C}=\right), 4.19-4.34(\mathrm{~m}, 4 \mathrm{H}$, $2 \times \mathrm{OCH}_{2} \mathrm{CH}_{3}$ ). Anal. Calcd for $\mathrm{C}_{22} \mathrm{H}_{39} \mathrm{ClO}_{4}$ (402.25): $\mathrm{C}, 65.57 ; \mathrm{H}$, 9.75; $\mathrm{Cl}, 8.80$. Found: $\mathrm{C}, 65.44 ; \mathrm{H}, 9.73 ; \mathrm{Cl}, 8.79$.

\subsubsection{Preparation of diethyl 2-(1-aminopentadecylidene)- malonate 7}

A solution of compound $\mathbf{5 a}(0.61 \mathrm{~g}, 1.59 \mathrm{mmol})$ in anhydrous ethanol $(10 \mathrm{~mL})$ was treated with ammonium acetate $(1.23 \mathrm{~g}$ $15.89 \mathrm{mmol}$ ) and the resulting mixture was stirred at room temperature for $2 \mathrm{~h}$. After completion (TLC monitoring, $\mathrm{SiO}_{2}$, $\mathrm{CHCl}_{3} / n$-hexane 3:1), the mixture was evaporated and the residue was treated with saturated sodium bicarbonate solution $(10 \mathrm{~mL})$ and extracted with ethyl acetate $(3 \times 15 \mathrm{~mL})$. The organic phases were combined, washed with brine $(3 \times 30 \mathrm{~mL})$, dried, and evaporated to obtain the required aminoester 7 as a TLC pure pale yellow oil (yield: 95\%). MS (EI, $70 \mathrm{eV}) \mathrm{m} / z: 383$ (100.0\%). ${ }^{1} \mathrm{H}$ NMR $\left(\mathrm{CDCl}_{3}\right) \delta$ $0.90\left(\mathrm{t}, 3 \mathrm{H}, \mathrm{CH}_{3}\right), 1.29-1.34\left(\mathrm{~m}, 28 \mathrm{H}, 11 \times \mathrm{CH}_{2}\right.$ and $2 \times \mathrm{OCH}_{2} \mathrm{CH}_{3}$, overlapped signals), $1.50-1.55\left(\mathrm{~m}, 2 \mathrm{H}, \quad \mathrm{CH}_{2} \mathrm{CH}_{2} \mathrm{C}\left(\mathrm{NH}_{2}\right)=\right)$, 
2.20-2.25 (m, 1H, $\left.\mathrm{CH}_{2} \mathrm{CHH}_{A} \mathrm{C}\left(\mathrm{NH}_{2}\right)=\right), \quad 2.38-2.43 \quad(\mathrm{~m}, \quad 1 \mathrm{H}$, $\left.\mathrm{CH}_{2} \mathrm{CHH}_{B} \mathrm{C}\left(\mathrm{NH}_{2}\right)=\right), 4.21-4.30\left(\mathrm{~m}, 4 \mathrm{H}, 2 \times \mathrm{OCH}_{2} \mathrm{CH}_{3}\right), 8.51$ (bs, $2 \mathrm{H}$, $\mathrm{NH}_{2}$, exchangeable with $\left.\mathrm{D}_{2} \mathrm{O}\right)$. Anal. Calcd for $\mathrm{C}_{22} \mathrm{H}_{41} \mathrm{NO}_{4}$ (383.30): C, 68.89; H, 10.77; N, 3.65. Found: C, 68.74; H, 10.75; N, 3.64 .

\subsubsection{Preparation of 2,2-dimethyl-5-pentadecylidene-1,3- dioxane-4,6-dione 8}

Title compound was prepared following the same procedure described for derivatives 1-3, starting from Meldrum's acid and pentadecanal 12b, as an oil (yield 80\%); ${ }^{1} \mathrm{H}$ NMR $\left(\mathrm{CDCl}_{3}\right): \delta 0.88(\mathrm{t}, 3 \mathrm{H}$, $\left.\mathrm{CH}_{3}\right), 1.26\left(\mathrm{~m}, 22 \mathrm{H}, 11 \times \mathrm{CH}_{2}\right), 1.57-1.62\left(\mathrm{~m}, 2 \mathrm{H}, \mathrm{CH}_{2} \mathrm{CH}_{2} \mathrm{C}=\right), 1.75$ (s, 6H, $\left.2 \times \mathrm{CH}_{3}\right)$ 2.91-2.96 (m, 2H, $\left.\mathrm{CH}_{2} \mathrm{C}=\right)$, $7.94(\mathrm{t}, 1 \mathrm{H}, \mathrm{CH})$; MS (EI, $70 \mathrm{eV}$ ) $\mathrm{m} / z$ (\%): 352. Anal. Calcd for $\mathrm{C}_{21} \mathrm{H}_{36} \mathrm{O}_{4}$ (352.26): $\mathrm{C}, 71.55 ; \mathrm{H}$, 10.29. Found: C, 71.44; H, 10.27 .

\subsubsection{Preparation of 2,2-dimethyl-5-pentadecyl-1,3-dioxane- 4,6-dione 9}

Title compound was prepared following the same procedure ${ }^{69}$ described for derivatives 4, starting from Meldrum's acid and pentadecylbromide, as an oil (yield 75\%); ${ }^{1} \mathrm{H}$ NMR $\left(\mathrm{CDCl}_{3}\right): \delta 0.88(\mathrm{t}$, $\left.3 \mathrm{H}, \mathrm{CH}_{3}\right), 1.26\left(\mathrm{~m}, 24 \mathrm{H}, 12 \times \mathrm{CH}_{2}\right), 1.43\left(\mathrm{~m}, 2 \mathrm{H}, \mathrm{CH}_{2} \mathrm{CH}_{2} \mathrm{CH}-\right)$, 1.76-1.78 (ds, 6H, $2 \times \mathrm{CH}_{3}$ ) 2.07-2.17 (m, 2H, $\mathrm{CH}_{2} \mathrm{CH}-$ ), 3.49 (t, $1 \mathrm{H}, \mathrm{CH}$ ); MS (EI, $70 \mathrm{eV}) \mathrm{m} / z$ (\%): 354. Anal. Calcd for $\mathrm{C}_{21} \mathrm{H}_{38} \mathrm{O}_{4}$ (354.28): C, 71.14; H, 10.80. Found: C, 70.98; H, 10.78.

\subsubsection{General procedure for the preparation of alkan-2-ylidene malonates 10a,b}

To a stirred and cooled $\left(-40^{\circ} \mathrm{C}\right)$ suspension of pentane-washed $\mathrm{NaH}$ (1.3 equiv, $60 \%$ suspension in oil) in dry THF $(10 \mathrm{~mL})$ was added triethyl phosphonoacetate (1.3 equiv) in THF (10 mL). After $1 \mathrm{~h}$ at room temperature, the mixture was cooled again $\left(-40^{\circ} \mathrm{C}\right)$, then a solution of the proper ketone (1 equiv) in THF $(10 \mathrm{~mL})$ was added dropwise and the mixture stirred for $18 \mathrm{~h}$ at room temperature. After completion (TLC monitoring, $\mathrm{SiO}_{2}, \mathrm{CHCl}_{3} / n$-hexane $3: 1$ ), the mixture was cautiously diluted with saturated aqueous ammonium chloride ( $20 \mathrm{~mL})$ and diethyl ether $(40 \mathrm{~mL})$, the organic layer separated and aqueous portion further extracted with ether $(2 \times 10 \mathrm{~mL})$. The combined organic extract was then washed with water and brine and finally dried. Solvent removal followed by column chromatography of the residue (silica gel, $\mathrm{CHCl}_{3} / n$-hexane $1: 1$ ) afforded the mixture of $E / Z$ diastereomers in $90 \%$ yield. A solution of this mixture ( 1 equiv) in dry THF $(8 \mathrm{~mL})$ was stirred at $-78^{\circ} \mathrm{C}$ under nitrogen and a solution of lithium diisopropylamide (1.5 equiv) and HMPA ( 2 equiv) in dry THF $(10 \mathrm{~mL})$ was introduced dropwise. The resulting mixture was stirred at $-78^{\circ} \mathrm{C}$ for $2 \mathrm{~h}$ before ethyl chloroformate ( 1.2 equiv) was added. The reaction mixture was warmed to room temperature gradually and stirred for another $45 \mathrm{~h}$. After completion (TLC monitoring, $\mathrm{SiO}_{2}, \mathrm{CHCl}_{3} / n$-hexane $1: 1)$, ether $(100 \mathrm{~mL})$ was added, and the reaction mixture was washed with saturated aqueous $\mathrm{NH}_{4} \mathrm{Cl}$ and brine. The organic layer was separated and the aqueous portion further extracted with ether $(2 \times 10 \mathrm{~mL})$. The combined organic extract was then washed with water and brine and finally dried over $\mathrm{Na}_{2} \mathrm{SO}_{4}$. Solvent removal furnished the TLC pure malonates.

Compound 10a: oil (yield 93\%); ${ }^{1} \mathrm{H}$ NMR $\left(\mathrm{CDCl}_{3}\right): \delta 0.89(\mathrm{t}, 3 \mathrm{H}$, $\left.\mathrm{CH}_{3}\right), 1.22-1.28\left(\mathrm{~m}, 26 \mathrm{H}, 10 \times \mathrm{CH}_{2}\right.$ and $2 \times \mathrm{OCH}_{2} \mathrm{CH}_{3}$, overlapped signals), 1.46 ( $\mathrm{m}, 2 \mathrm{H}, \mathrm{CH}_{2} \mathrm{CH}_{2} \mathrm{C}=$ ), 2.02 (s, 3H, $\mathrm{CH}_{3} \mathrm{C}=$ ), 2.26-2.31 $\left(\mathrm{m}, 2 \mathrm{H}, \mathrm{CH}_{2} \mathrm{C}=\right), 4.14-4.22\left(\mathrm{~m}, 4 \mathrm{H}, 2 \times \mathrm{OCH}_{2} \mathrm{CH}_{3}\right.$, overlapped signals); $\mathrm{MS}$ (EI, $70 \mathrm{eV}) \mathrm{m} / z$ (\%): 368. Anal. Calcd for $\mathrm{C}_{22} \mathrm{H}_{40} \mathrm{O}_{4}$ (368.29): C, 71.70; H, 10.94. Found: C, 71.63; H, 10.93.

Compound 10b: oil (yield 92\%); ${ }^{1} \mathrm{H}$ NMR $\left(\mathrm{CDCl}_{3}\right): \delta 0.88(\mathrm{t}, 3 \mathrm{H}$, $\left.\mathrm{CH}_{3}\right), 1.21-1.30\left(\mathrm{~m}, 28 \mathrm{H}, 11 \times \mathrm{CH}_{2}\right.$ and $2 \times \mathrm{OCH}_{2} \mathrm{CH}_{3}$, overlapped signals), $1.50\left(\mathrm{~m}, 2 \mathrm{H}, \mathrm{CH}_{2} \mathrm{CH}_{2} \mathrm{C}=\right), 2.05$ (s, 3H, $\left.\mathrm{CH}_{3} \mathrm{C}=\right), 2.29-2.34$ $\left(\mathrm{m}, 2 \mathrm{H}, \mathrm{CH}_{2} \mathrm{C}=\right), 4.18-4.26\left(\mathrm{~m}, 4 \mathrm{H}, 2 \times \mathrm{OCH}_{2} \mathrm{CH}_{3}\right.$, overlapped signals); $\mathrm{MS}$ (EI, $70 \mathrm{eV}$ ) $\mathrm{m} / z$ (\%): 382. Anal. Calcd for $\mathrm{C}_{23} \mathrm{H}_{42} \mathrm{O}_{4}$ (382.31): C, 72.21; H, 11.07. Found: C, 72.06; H, 11.05.

\subsubsection{Preparation of diethyl 2-((tridecylamino)methylene)- malonates 11}

A solution of diethyl ethoxymethylenemalonate $(500 \mu \mathrm{L}$, $2.45 \mathrm{mmol})$ in dry ethanol $(2 \mathrm{~mL})$ was added to a stirred solution of tridecylamine $(0.41 \mathrm{~g}, 2.00 \mathrm{mmol})$ in dry ethanol $(8 \mathrm{~mL})$ and the resulting mixture was refluxed overnight. After completion (TLC monitoring, $\mathrm{SiO}_{2}, \mathrm{CHCl}_{3} / n$-hexane $1: 1$ ), the solvent was removed under reduced pressure to obtain title compound as a TLC pure oil (yield 99\%). ${ }^{1} \mathrm{H}$ NMR $\left(\mathrm{CDCl}_{3}\right): \delta 0.88\left(\mathrm{t}, 3 \mathrm{H}, \mathrm{CH}_{3}\right)$, 1.18-1.36 $\left(\mathrm{m}, 26 \mathrm{H}, 10 \times \mathrm{CH}_{2}\right.$ and $2 \times \mathrm{OCH}_{2} \mathrm{CH}_{3}$, overlapped signals), $1.57\left(\mathrm{~m}, 2 \mathrm{H}, \mathrm{CH}_{2} \mathrm{CH}_{2} \mathrm{NH}=\right), 3.28-3.27\left(\mathrm{~m}, 2 \mathrm{H}, \mathrm{CH}_{2} \mathrm{NH}=\right)$, 4.14-4.27 ( $\mathrm{m}, 4 \mathrm{H}, 2 \times \mathrm{OCH}_{2} \mathrm{CH}_{3}$, overlapped signals), 7.97-8.01 (d, 1H, CH), 9.22 (br m, 1H, NH); MS (EI, $70 \mathrm{eV}$ ) m/z (\%): 369. Anal. Calcd for $\mathrm{C}_{21} \mathrm{H}_{39} \mathrm{NO}_{4}$ (369.29): C, 68.25; H, 10.64; N, 3.79. Found: C, $68.11 ; \mathrm{H}, 10.62 ; \mathrm{N}, 3.78$.

\subsection{Biology}

\subsubsection{Cell culture}

Human leukemia cell lines U937 was propagated in RPMI medium supplemented with 10\% FBS (Foetal bovine serum; Hyclone) and antibiotics ( $100 \mathrm{U} / \mathrm{mL}$ penicillin, $100 \mu \mathrm{g} / \mathrm{mL}$ streptomycin and $250 \mathrm{ng} / \mathrm{mL}$ amphotericin-B). MCF7 cells were grown in the same condition but with D-MEM medium. Both cell lines were kept at the constant concentration of 200,000 cells per $\mathrm{mL}$ of culture medium, at the temperature of $37^{\circ} \mathrm{C}$ and with $5 \%$ of $\mathrm{CO}_{2}$.

\subsubsection{Ligands and materials}

Anacardic acid (Alexis) and SAHA ${ }^{76}$ were dissolved in DMSO and used at 50 and $5 \mu \mathrm{M}$, respectively.

\subsubsection{Expression and purification of KAT3B (p300)}

$\mathrm{His}_{6}$-tagged human p300 was expressed in Sf9 cells from a baculovirus-based plasmid (kind gift of Professor Alexandra Lusser and Professor James T. Kadonaga) and purified by affinity chromatography on Ni-NTA affinity resin (Qiagen) as described elsewhere. $^{79}$ Protein was eluted with buffer containing $250 \mathrm{mM}$ imidazole, frozen in liquid nitrogen, and stored at $-80^{\circ} \mathrm{C}$. p300 concentrations and purity were estimated by Bradford protein assays (Bio-Rad) and by comparison to BSA standards on SDS gels stained with Coomassie Brilliant Blue G-250.

\subsubsection{Human recombinant KAT3A (CBP) assay}

The recombinant CBP was prepared in Escherichia coli BL21 and purified by affinity chromatography. Recombinant CBP fraction corresponded to amino acids 1098-1877. CBP was incubated in HAT buffer (50 mM Tris-HCl pH 8.0, 10\% glycerol, 0.1 mM EDTA, $1 \mathrm{mM}$ DTT) with $10 \mu \mathrm{g}$ of histone $\mathrm{H} 4$ peptide (corresponding to amino acids 2-24) and $20 \mu \mathrm{M}$ acetyl-CoA containing $0.5 \mu \mathrm{Ci} / \mathrm{mL}$ $\left[{ }^{3} \mathrm{H}\right]$-acetyl-CoA in the presence of tested compounds at selected concentrations. After $2 \mathrm{~h}$ a $37^{\circ} \mathrm{C}, 5 \mu \mathrm{L}$ of samples were spotted onto Whatman P81 paper (in triplicate). The paper squares were washed three times in 5\% TCA and once in 100\% acetone and then placed into scintillation vials containing scintillation fluid to allow the DPM reading. The DPM of enzyme samples was compared to DPM of negative control. Data have been expressed as percentage.

\subsubsection{KAT2B (PCAF)assays}

PCAF radioactive assay was performed according to general indications provided by UPSTATE radioactive KIT. Human PCAF (200 ng) was incubated in KAT buffer (Upstate) with $10 \mu \mathrm{g}$ of histone $\mathrm{H} 4$ peptide substrate (corresponding to aminoacids 2-24) and $20 \mu \mathrm{M}$ acetyl-CoA containing $0.5 \mu \mathrm{Ci} / \mathrm{mL}\left[{ }^{3} \mathrm{H}\right]$ acetyl-CoA. 
The acetylation reaction was performed in a volume of $25 \mu \mathrm{L}$ in the presence of testing compounds at the desired final concentration. After $2 \mathrm{~h}$ a $37^{\circ} \mathrm{C}, 5 \mu \mathrm{L}$ of samples were spotted onto chromatographic Whatman P81 paper (in triplicate). After a washing session (three times in 5\% TCA and once in 100\% acetone), the paper squares were placed into scintillation vials containing scintillation fluid to allow the DPM reading. The DPM of enzyme samples was compared to DPM of negative and positive control and reported as \% of activity considering the untreated control as $100 \%$.

\subsubsection{Protein extraction protocol}

MCF-7 and U937 cells were treated with reference compound or tested derivatives and harvested by centrifugation. After PBS wash, the samples were resuspended in a lysis buffer $(50 \mathrm{mM}$ Tris- $\mathrm{HCl}$ $\mathrm{pH} 7.4,150 \mathrm{mM} \mathrm{NaCl}, 1 \% \mathrm{NP} 40,10 \mathrm{mM}$ sodium fluoride, $1 \mathrm{mM}$ PMSF and protease inhibitor cocktail), and the lysis reaction was carried out for $15 \mathrm{~min}$ at $4^{\circ} \mathrm{C}$. The samples were centrifuged at $13,000 \mathrm{rpm}$ for $30 \mathrm{~min}$ at $4{ }^{\circ} \mathrm{C}$, and the proteins were quantified by the Bradford assay (Bio-Rad).

\subsubsection{Histone extraction protocol}

Cells were harvested and washed twice with ice-cold PBS and lysed in Triton Extraction Buffer (TEB: PBS containing 0.5\% Triton X $100(\mathrm{v} / \mathrm{v}), 2 \mathrm{mM}$ phenylmethylsulfonyl fluoride (PMSF), 0.02\% $\left.(\mathrm{w} / \mathrm{v}) \mathrm{NaN}_{3}\right)$ at a cellular density of $10^{7}$ cells per $\mathrm{mL}$ for $10 \mathrm{~min}$ on ice, with gentle stirring. After a brief centrifugation at $2000 \mathrm{rpm}$ at $4{ }^{\circ} \mathrm{C}$, the supernatant was removed and the pellet was washed in half the volume of TEB and centrifuged as before. The pellet was resuspended in $0.2 \mathrm{M} \mathrm{HCl}$ at a cell density of $4 \times 10^{7}$ cells per $\mathrm{mL}$ and acid extraction was left to proceed overnight at $4{ }^{\circ} \mathrm{C}$ on a rolling table. Next, the samples were centrifuged at $2000 \mathrm{rpm}$ for $10 \mathrm{~min}$ at $4{ }^{\circ} \mathrm{C}$, the supernatant was removed and its protein content was determined using the Bradford assay (BioRad).

\subsubsection{Western blot analyses}

Western Blot analyses were performed according to standard procedures following suggestions of antibody suppliers. For $\alpha$-tubulin, an amount of $30 \mu \mathrm{g}$ for MCF-7 cells of total protein extracts was separated on $10 \%$ polyacrylamide gels and blotted. ${ }^{80}$ For the histone H3 and H4 acetylations in U937 and MCF7 cells, $10 \mu \mathrm{g}$ of histone extract was separated on $15 \%$ polyacrylamide gels and blotted. ${ }^{80}$ The blotted nitrocellulose was washed twice with water and then blocked in freshly prepared PBS, containing 5\% nonfat dry milk (PBS-MLK) for one hour at room temperature with constant agitation. The nitrocellulose was incubated with 1:1000 dilution of anti acetylated $\alpha$-tubulin (Sigma), pan-acetylated histone H3 (Upstate), H3K9ac (Abcam), H3K14ac (Abcam), H3K18ac (Abcam), H3K56ac (Abcam), H4K5ac (Abcam), H4K8ac (Abcam), H4K16ac (Abcam), and pan-acetylated H4 (Abcam). ERK-1 (extracellular signal-regulated kinase-1, Santa Cruz) antibody, Ponceau Red (Sigma) staining, and histone H1 (Abcam) were used, respectively, to normalize for equal loading.

5.2.8.1. Cell cycle analysis. The $2.5 \times 10^{5}$ cells were collected and resuspended in $500 \mu \mathrm{L}$ of an hypotonic buffer $(0.1 \%$ Triton $\mathrm{X}$ $100,0.1 \%$ sodium citrate, $50 \mu \mathrm{g} / \mathrm{mL}$ propidium iodide, RNAse A). Cells were incubated in the dark for $30 \mathrm{~min}$. Samples were acquired on a FACS-Calibur flow cytometer using the Cell Quest software (Becton Dickinson) and analyzed with standard procedures using the Cell Quest software (Becton Dickinson) and the ModFit LT version 3 software (Verity). All the experiments were performed three times.

5.2.8.2. FACS analysis of apoptosis.

Apoptosis was measured with Annexin V/propidium iodide double-staining detection
(Roche and Sigma-Aldrich, respectively), as recommended by the suppliers. Samples were analyzed by FACS with Cell Quest technology (Becton Dickinson). As second assays, the caspase 3 detection (B-Bridge) was performed and quantified by FACS (data not shown, Becton Dickinson).

5.2.8.3. Kinetic study of the interaction with KAT3B. SPR analyses were performed on a Biacore 3000 optical biosensor equipped with research-grade CM5 sensor chips (Biacore $A B$ ). ${ }^{81}$ Using this platform, two separate KAT3B (p300, both the full length protein and its KAT domain) surfaces, one BSA surface and one unmodified reference surface were prepared for simultaneous analyses. Proteins $\left(30 \mu \mathrm{g} \mathrm{mL}^{-1}\right.$ in $10 \mathrm{mM}$ sodium acetate, $\mathrm{pH}$ 4.0) were immobilized on individual flow cells of the sensor chip at a flow rate of $10 \mathrm{~mL} \mathrm{~min}^{-1}$ by using standard amine-coupling protocols ${ }^{82}$ to obtain densities of 8-14 kRU. Compounds 1-3 were dissolved in DMSO (100\%) to obtain

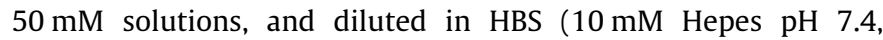
$0.15 \mathrm{M} \mathrm{NaCl}, 0.005 \% \mathrm{NP} 40$ ) with a final DMSO concentration of $0.5 \%$. Binding experiments were performed at $25^{\circ} \mathrm{C}$, by using a flow rate of $30 \mu \mathrm{L} \mathrm{min}^{-1}$, with $120 \mathrm{~s}$ monitoring of association and $400 \mathrm{~s}$ monitoring of dissociation. Regeneration of the surfaces was performed, when necessary, by a $10 \mathrm{~s}$ injection of $5 \mathrm{mM} \mathrm{NaOH}$.

\section{Acknowledgments}

This work was partially supported by grants from Ministero dell'Università e della Ricerca Scientifica e Tecnologica-PRIN 2008, (S.C.), Fondazione Roma (A.M.), and Università di Salerno, Italy (G.S.). L.A. is supported by AIRC and 'ATLAS' HEALTH-F42009-221952.

We are grateful to Professor Alexandra Lusser and Professor James T. Kadonaga for the kind gift of p300 baculovirus expression construct.

\section{Supplementary data}

Supplementary data (experimental procedures for determination of granulocytic differentiation, KDAC assay, fluorescent KAT3B assay and additional graphs) associated with this article can be found, in the online version, at doi:10.1016/j.bmc.2011.01.013.

\section{References and notes}

1. Kouzarides, T. Cell 2007, 128, 693.

2. Berger, S. L. Nature 2007, 447, 407.

3. Ruthenburg, A. J.; Li, H.; Patel, D. J.; Allis, C. D. Nat. Rev. Mol. Cell Biol. 2007, 8, 983.

4. Strahl, B. D.; Allis, C. D. Nature 2000, 403, 41

5. Allfrey, V. G.; Faulkner, R.; Mirsky, A. E. Proc. Natl. Acad. Sci. U.S.A. 1964, 51, 786

6. Roth, S. Y.; Denu, J. M.; Allis, C. D. Annu. Rev. Biochem. 2001, 70, 81.

7. Yang, X.-J.; Seto, E. Mol. Cell 2008, 31, 449.

8. Liu, Y.; Colosimo, A. L.; Yang, X.-J.; Liao, D. Mol. Cell. Biol. 2000, 20, 5540.

9. Hubbert, C.; Guardiola, A.; Shao, R.; Kawaguchi, Y.; Ito, A.; Nixon, A.; Yoshida, M.; Wang, X.-F.; Yao, T.-P. Nature 2002, 417, 455.

10. Glozak, M. A.; Sengupta, N.; Zhang, X.; Seto, E. Gene 2005, 363, 15.

11. Matthias, P.; Yoshida, M.; Khochbin, S. Cell Cycle 2008, 7, 7.

12. Yang, X.-J.; Seto, E. Nat. Rev. Mol. Cell Biol. 2008, 9, 206.

13. Arif, M.; Selvi, B. R.; Kundu, T. K. ChemBioChem 2010, 11, 1501.

14. von Wantoch Rekowski, M.; Giannis, A. Biochim. Biophys. Acta, Gene Regul. Mech. 2010, 1799, 760.

15. Zhao, S.; Xu, W.; Jiang, W.; Yu, W.; Lin, Y.; Zhang, T.; Yao, J.; Zhou, L.; Zeng, Y.; Li, H.; Li, Y.; Shi, J.; An, W.; Hancock, S. M.; He, F.; Qin, L.; Chin, J.; Yang, P.; Chen, X.; Lei, Q.; Xiong, Y.; Guan, K.-L. Science 2010, 327, 1000.

16. Wang, Q.; Zhang, Y.; Yang, C.; Xiong, H.; Lin, Y.; Yao, J.; Li, H.; Xie, L.; Zhao, W. Yao, Y.; Ning, Z.-B.; Zeng, R.; Xiong, Y.; Guan, K.-L.; Zhao, S.; Zhao, G.-P. Science 2010, 327, 1004.

17. Allis, C. D.; Berger, S. L.; Cote, J.; Dent, S.; Jenuwien, T.; Kouzarides, T.; Pillus, L.; Reinberg, D.; Shi, Y.; Shiekhattar, R.; Shilatifard, A.; Workman, J.; Zhang, Y. Cell 2007, 131, 633. 
18. Lysine acetylation was initially identified in histones, so many KATs and KDACs are often referred to as histone acetyltransferases (HATs) and deacetylases (HDACs), respectively.

19. Dekker, F. J.; Haisma, H. J. Drug Discovery Today 2009, 14, 942.

20. Manzo, F.; Tambaro, F. P.; Mai, A.; Altucci, L. Expert Opin. Ther. Pat. 2009, 19, 761.

21. Howe, L.; Auston, D.; Grant, P.; John, S.; Cook, R. G.; Workman, J. L.; Pillus, L. Genes Dev. 2001, 15, 3144.

22. Gayther, S. A.; Batley, S. J.; Linger, L.; Bannister, A.; Thorpe, K.; Chin, S.-F.; Daigo, Y.; Russell, P.; Wilson, A.; Sowter, H. M.; Delhanty, J. D. A.; Ponder, B. A. J.; Kouzarides, T.; Caldas, C. Nat. Genet. 2000, 24, 300.

23. Bandyopadhyay, D.; Okan, N. A.; Bales, E.; Nascimento, L.; Cole, P. A.; Medrano, E. E. Cancer Res. 2002, 62, 6231.

24. Giordano, A.; Avantaggiati, M. L. J. Cell. Physiol. 1999, 181, 218.

25. Pfister, S.; Rea, S.; Taipale, M.; Mendrzyk, F.; Straub, B.; Ittrich, C.; Thuerigen, O.; Sinn, H. P.; Akhtar, A.; Lichter, P. Int. J. Cancer 2008, 122, 1207.

26. Katsumoto, T.; Yoshida, N.; Kitabayashi, I. Cancer Sci. 2008, 99, 1523.

27. Iyer, N. G.; Xian, J.; Chin, S. F.; Bannister, A. J.; Daigo, Y.; Aparicio, S.; Kouzarides, T.: Caldas, C. Oncogene 2007, 26, 21.

28. Kitabayashi, I.; Aikawa, Y.; Yokoyama, A.; Hosoda, F.; Nagai, M.; Kakazu, N.; Abe, T.; Ohki, M. Leukemia 2001, 15, 89.

29. Ait-Si-Ali, S.; Polesskaya, A.; Filleur, S.; Ferreira, R.; Duquet, A.; Robin, P.; Vervish, A.; Trouche, D.; Cabon, F.; Harel-Bellan, A. Oncogene 2000, 19, 2430.

30. Adcock, I. M.; Tsaprouni, L.; Bhavsar, P.; Ito, K. Curr. Opin. Immunol. 2007, 19, 694.

31. Yang, X. J. Nucleic Acids Res. 2004, 32, 959.

32. Mantelingu, K.; Reddy, B. A. A.; Swaminathan, V.; Kishore, A. H.; Siddappa, N. B.; Kumar, G. V. P.; Nagashankar, G.; Natesh, N.; Roy, S.; Sadhale, P. P.; Ranga, U.; Narayana, C.; Kundu, T. K. Chem. Biol. 2007, 14, 645.

33. Barnes, P. J.; Adcock, I. M.; Ito, K. Eur. Resp. J. 2005, 25, 552.

34. Lau, O. D.; Kundu, T. K.; Soccio, R. E.; Ait-Si-Ali, S.; Khalil, E. M.; Vassilev, A.; Wolffe, A. P.; Nakatani, Y.; Roeder, R. G.; Cole, P. A. Mol. Cell 2000, 5, 589

35. Saha, R. N.; Pahan, K. Cell Death Differ. 2005, 13, 539.

36. Rouaux, C.; Jokic, N.; Mbebi, C.; Boutillier, S.; Loeffler, J.-P.; Boutillier, A.-L. EMBO J. 2003, 22, 6537.

37. Barrett, R. M.; Wood, M. A. Learn. Memory 2008, 15, 460.

38. Maurice, T.; Duclot, F.; Meunier, J.; Naert, G.; Givalois, L.; Meffre, J.; Celerier, A.; Jacquet, C.; Copois, V.; Mechti, N.; Ozato, K.; Gongora, C. Neuropsychopharmacology 2007, 33, 1584.

39. Mai, A.; Massa, S.; Rotili, D.; Cerbara, I.; Valente, S.; Pezzi, R.; Simeoni, S.; Ragno, R. Med. Res. Rev. 2005, 25, 261.

40. Minucci, S.; Pelicci, P. G. Nat. Rev. Cancer 2006, 6, 38.

41. Richon, V. M.; Emiliani, S.; Verdin, E.; Webb, Y.; Breslow, R.; Rifkind, R. A.; Marks, P. A. Proc. Natl. Acad. Sci. U.S.A. 1998, 95, 3003.

42. Nakajima, H.; Kim, Y. B.; Terano, H.; Yoshida, M.; Horinouchi, S. Exp. Cell. Res. 1998, 241, 126.

43. Nagy, Z: Tora, L. Oncogene 2007, 26, 5341.

44. Marmorstein, R.; Trievel, R. C. Biochim. Biophys. Acta, Gene Regul. Mech. 2009, 1789, 58.

45. Lee, K. K.; Workman, J. L. Nat. Rev. Mol. Cell Biol. 2007, 8, 284

46. Hodawadekar, S. C.; Marmorstein, R. Oncogene 2007, 26, 5528.

47. Brownell, J. E.; Zhou, J.; Ranalli, T.; Kobayashi, R.; Edmondson, D. G.; Roth, S. Y.; Allis, C. D. Cell 1996, 84, 843.

48. Stockwell, B. R. Nat. Rev. Genet. 2000, 1, 116.

49. Bowers, E. M.; Yan, G.; Mukherjee, C.; Orry, A.; Wang, L.; Holbert, M. A.; Crump N. T.; Hazzalin, C. A.; Liszczak, G.; Yuan, H.; Larocca, C.; Saldanha, S. A. Abagyan, R.; Sun, Y.; Meyers, D. J.; Marmorstein, R.; Mahadevan, L. C.; Alani, R. M.; Cole, P. A. Chem. Biol. 2010, 17, 471.

50. Cebrat, M.; Kim, C. M.; Thompson, P. R.; Daugherty, M.; Cole, P. A. Bioorg. Med. Chem. 2003, 11, 3307.
51. Balasubramanyam, K.; Swaminathan, V.; Ranganathan, A.; Kundu, T. K. J. Biol. Chem. 2003, 278, 19134.

52. Balasubramanyam, K.; Altaf, M.; Varier, R. A.; Swaminathan, V.; Ravindran, A.; Sadhale, P. P.; Kundu, T. K. J. Biol. Chem. 2004, 279, 33716.

53. Balasubramanyam, K.; Varier, R. A.; Altaf, M.; Swaminathan, V.; Siddappa, N. B.; Ranga, U.; Kundu, T. K. J. Biol. Chem. 2004, 279, 51163.

54. Ravindra, K. C.; Selvi, B. R.; Arif, M.; Reddy, B. A. A.; Thanuja, G. R.; Agrawal, S.; Pradhan, S. K.; Nagashayana, N.; Dasgupta, D.; Kundu, T. K. J. Biol. Chem. 2009 284, 24453.

55. Dal Piaz, F.; Tosco, A.; Eletto, D.; Piccinelli, A. L.; Moltedo, O.; Franceschelli, S.; Sbardella, G.; Remondelli, P.; Rastrelli, L.; Vesci, L.; Pisano, C.; De Tommasi, N. ChemBioChem 2010, 11, 818.

56. Eliseeva, E. D.; Valkov, V.; Jung, M.; Jung, M. O. Mol. Cancer Ther. 2007, 6, 2391.

57. Ghizzoni, M.; Boltjes, A.; Graaf, C. D.; Haisma, H. J.; Dekker, F. J. Bioorg. Med. Chem. 2010, 18, 5826

58. Souto, J. A.; Conte, M.; Álvarez, R.; Nebbioso, A.; Carafa, V.; Altucci, L.; de Lera, A. R. ChemMedChem 2008, 3, 1435.

59. Costi, R.; Di Santo, R.; Artico, M.; Miele, G.; Valentini, P.; Novellino, E.; Cereseto, A. J. Med. Chem. 2007, 50, 1973 .

60. Mai, A.; Cheng, D.; Bedford, M. T.; Valente, S.; Nebbioso, A.; Perrone, A.; Brosch, G.; Sbardella, G.; De Bellis, F.; Miceli, M.; Altucci, L. J. Med. Chem. 2008, 51, 2279.

61. Dekker, F. J.; Ghizzoni, M.; van der Meer, N.; Wisastra, R.; Haisma, H. J. Bioorg. Med. Chem. 2009, 17, 460.

62. Ghizzoni, M.; Haisma, H. J.; Dekker, F. J. Eur. J. Med. Chem. 2009, 44, 4855.

63. Gorsuch, S.; Bavetsias, V.; Rowlands, M. G.; Aherne, G. W.; Workman, P.; Jarman, M.; McDonald, E. Bioorg. Med. Chem. 2009, 17, 467.

64. Stimson, L.; Rowlands, M. G.; Newbatt, Y. M.; Smith, N. F.; Raynaud, F. I.; Rogers, P.; Bavetsias, V.; Gorsuch, S.; Jarman, M.; Bannister, A.; Kouzarides, T.; McDonald, E.; Workman, P.; Aherne, G. W. Mol. Cancer Ther. 2005, 4, 1521.

65. Biel, M.; Kretsovali, A.; Karatzali, E.; Papamatheakis, J.; Giannis, A. Angew. Chem., Int. Ed. 2004, 43, 3974.

66. Mai, A.; Rotili, D.; Tarantino, D.; Ornaghi, P.; Tosi, F.; Vicidomini, C.; Sbardella, G.: Nebbioso, A. Miceli, M.: Altucci, L.; Filetici, P. J. Med Chem 2006, 49, 6897.

67. Sbardella, G.; Castellano, S.; Vicidomini, C.; Rotili, D.; Nebbioso, A.; Miceli, M.; Altucci, L.; Mai, A. Bioorg. Med. Chem. Lett. 2008, 18, 2788.

68. Dess, D. B.; Martin, J. C. J. Am. Chem. Soc. 1991, 113, 7277.

69. Haldar, J.; Kondaiah, P.; Bhattacharya, S. J. Med. Chem. 2005, 48, 3823.

70. Ahlquist, L.; Asselineau, C.; Asselineau, J.; Stallberg-Stenhagen, S.; Stenhagen, E. Ark. Kemi 1958, 31, 543.

71. Comeau, D.; Lai, R.; Charlot, C.; Ucciani, E. Bull. Soc. Chim. Fr. 1972, 4163.

72. Actually, as noticeable in Figure 5B, a slight acetylation was observed for both compounds at $15 \mu \mathrm{M}$ concentration. Yet, it was completely undetectable at $30 \mu \mathrm{M}$.

73. Varier, R. A.; Swaminathan, V.; Balasubramanyam, K.; Kundu, T. K. Biochem. Pharmacol. 2004, 68, 1215.

74. In these conditions, compound $\mathbf{2 b}$ caused excessive cell death.

75. In Figure 8 as well as in the text we used the 'Brno nomenclature' to indicate specific acetylation sites. See also: Turner, B. M. Nat. Struct. Mol. Biol. 2005, 12, 110.

76. Mai, A.; Esposito, M.; Sbardella, G.; Massa, S. Org. Prep. Proced. Int. 2001, 33, 391.

77. Chang, Y.-H.; Uang, B.-J.; Wu, C.-M.; Yu, T.-H. Synthesis 1990, 1990, 1033.

78. Sorg, G.; Mengel, A.; Jung, G.; Rademann, J. Angew. Chem., Int. Ed. 2001, 40, 4395.

79. Kraus, W. L.; Kadonaga, J. T. Genes Dev. 1998, 12, 331.

80. Nebbioso, A.; Clarke, N.; Voltz, E.; Germain, E.; Ambrosino, C.; Bontempo, P.; Alvarez, R.; Schiavone, E. M.; Ferrara, F.; Bresciani, F.; Weisz, A.; de Lera, A. R.; Gronemeyer, H.; Altucci, L. Nat. Med. 2005, 11, 77.

81. Cooper, M. Anal. Bioanal. Chem. 2003, 377, 834.

82. Johnsson, B.; Löfås, S.; Lindquist, G. Anal. Biochem. 1991, 198, 268. 